\title{
Ecological Evaluation of \\ Proposed Dredged Material from the Point Frazier Bend Reach, Winyah Bay, South Carolina
}

W. W. Gardiner

J. A. Ward

J. Q. Word

Battelle/Marine Sciences Laboratory

Sequim, Washington

February 1995

Prepared for the

U.S. Army Corps of Éngineers under a Related Services Agreement with the U.S. Department of Energy Contract DE-AC06-76RLO 1830

Pacific Northwest Laboratory Operated for the U.S. Department of Energy by Battelle Memorial Institute 

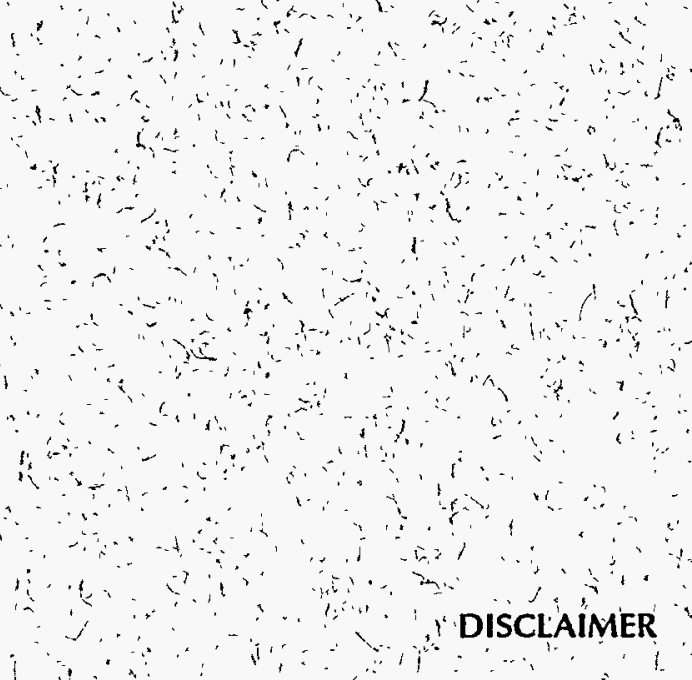

This report was prepared as an account of work sponsöred by an agency of the United States Government. Néither the United States Government nor any agency thereof, nor Battelle Memorial Institute, nor any of their employees, makes any. warranty, expressed or implied, orássumes any legal liability or responsibility for the accuracy, complèteness or usefulness of any information, a pparatus, product, orprocess disclosed, or represents that its use would not infringe privately owned rights: Reference herein to any sṕecific commercial product, process, or service by trade name, trademark, manufacturér, or otherwise does not necessarily constitute or imply its endorsement, recommendation, or favoring by the ,United States Government or any agency thereof, or Battelle Memorial, Instifute. The views and 'opinions of authors expressed herein do not necessarily state or reflect those of the United Státes Covernment or any ágency thereof.

\section{PACIFIC NORTHWEST LABORATORY: operated by \\ BATTELLE MEMORIALINSTITUTE for the \\ UNITED,STÁTES DEPARTMENTT OFENERGY under Contráct DE-ACO6-76RLO 1830}
Printed in the United States of America'
Office of Scientific and Technicál Informátion,P.O. Box 62, Oak Ridgé, TN 378́31; prices available from (615) $576-8401$. FTS 626-8401.'

I Available to the public from the National Technical Information Service, UU.S. Department of Commerce, 5285 Port Royal Rd,s Springfield, VA 22161. 
PNL-10452

UC-403

\section{ECOLOGICAL EVALUATION OF PROPOSED DREDGED MATERIAL FROM THE POINT FRAZIER BEND REACH, WINYAH BAY, SOUTH CAROLINA}

W. W. Gardiner

J. A. Ward

J. Q. Word

Battelle/Marine Sciences Laboratory

Sequim, Washington

February 1995

Prepared for

U.S. Army Corps of Engineers under a Related Services Agreement with the U.S. Department of Energy Contract DE-AC06-76RLO 1830

Pacific Northwest Laboratory Richland, Washington 99352 



\section{DISCLAIMER}

Portions of this document may be illegible in electronic image products. Images are produced from the best available original document. 


\section{SUMMARY}

The port of Georgetown, South Carolina, is served by navigational channels within Winyah Bay and the lower Sampit River. Dredging is required to maintain these waterways and to facilitate normal shipping traffic. Prior to dredging, ecological evaluations must be conducted to determine the suitability of the proposed dredged material for open-ocean disposal. These evaluations are to be performed under Section 103 of the Marine Protection, Research, and Sanctuaries Act of 1972 (MPRSAl, following the testing protocols presented in Evaluation of Dredged Material Proposed for Ocean Disposal Testing Manual, hereafter referred to as the 1991 Implementation Manual. The Charleston Intensive Project is a reevaluation of sediments collected from two stations (IH-2 and $\mathrm{IH}-3)$ in the Frazier Point Bend reach of the Winyah Bay channel. Reference sediment was also collected from site IH-R2, just south of Hare Island. In support of the Charleston Intensive Program, Battelle/Marine Sciences Laboratory carried out the following:

- characterized sediment samples representing proposed dredged material (test treatments) and the reference sediment sample (reference treatment) through physical/chemical analyses. In addition, a field-collected rinsate blank was collected and analyzed for chemical contamination.

- evaluated water-column acute toxicity of test treatments $\mathrm{IH}-2$ and $\mathrm{IH}-3$ with suspended-particulate-phase (SPP) tests using the mysid Mysidopsis bahia, the silverside Menidia beryllina, and larvae of the sea urchin Lytechinus pictus. Toxicological results of test treatments were compared to those observed in seawater-only controls. An $\mathrm{LC}_{50}$ or $\mathrm{EC}_{50}$, that concentration evoking a lethal or sublethal effect in $50 \%$ of the population, was calculated when at least a $50 \%$ decrease response relative to control was observed.

- $\quad$ performed appropriate comparisons of results through statistical analyses to determine compliance of the proposed dredged material with Section 103 of MPRSA. .

The results of physical/chemical analyses indicated that some contaminants of concern were present in test treatments representing dredged material when compared with the reference treatment IH-R2. Elevated levels of polynuclear aromatic hydrocarbons (PAHs) were observed in test treatment IH-3. Dioxin congeners were virtually absent in all test treatments; only ubiquitous congeners were detected. Metals were below those in reference sediment in station $\mathrm{IH}-2$. Copper, chromium, and zinc were slightly elevated in 
station $\mathrm{IH}-3$, relative to levels in the reference sediment. Organotins were not detected in any of the sediments samples. Chemical analyses of a rinsate blank revealed no elevated levels of any contaminant and indicate that field contamination of sediments did not occur throughout the sampling process. Contaminant levels in 1994 were substantially lower than those measured in 1992 for sediments collected from these two stations. This could be associated with the reduced clay/silt content of these samples in 1994.

The SPP exposures were not acutely toxic to M. bahia, M. beryllina, or L. pictus. Statistical analyses of these data showed no evidence of significantly decreased $M$. beryllina survival in the IH-3 SPP; however, because mortality was less than $50 \%$, no $\mathrm{LC}_{50}$ could be generated. An $\mathrm{EC}_{50}$ of $66.9 \% \mathrm{IH}-3$ SPP was calculated for the $L$. pictus test, indicating that normal development was affected by this SPP.

The results of this study indicate that, based on the acute toxicity and chemical analyses, dredged material represented by these test treatments is in compliance with Appendixes A and B of the 1991 Implementation Manual and is suitable for open-ocean disposal. The results generated by this study can be used by the U.S. Army Corps of Engineers in its decision-making process regarding acceptable disposal options for the sediments from the Frazier Point Bend reach in Winyah Bay. 


\section{CONTENTS}

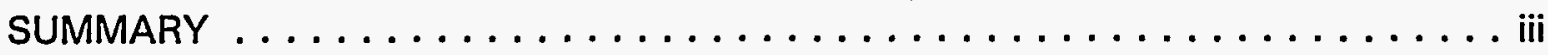

1.0 INTRODUCTION ..........................

2.0 MATERIALS AND METHODS . . . . . . . . . . . . . . 2.1

2.1 SAMPLE COLLECTION $\ldots \ldots \ldots \ldots \ldots \ldots \ldots \ldots \ldots \ldots \ldots \ldots \ldots$

2.2 SAMPLE, GLASSWARE, AND EQUIPMENT PREPARATION . . . . . 2.1

2.3 SAMPLE CHEMISTRY PROCEDURES $\ldots \ldots \ldots \ldots \ldots \ldots \ldots \ldots$

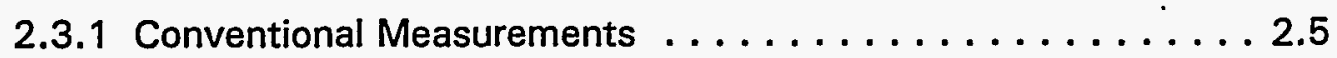

2.3.2 Polynuclear Aromatic Hydrocarbons . . . . . . . . . 2.5

2.3.3 Dioxins and Furans $\ldots \ldots \ldots \ldots \ldots \ldots \ldots \ldots \ldots$

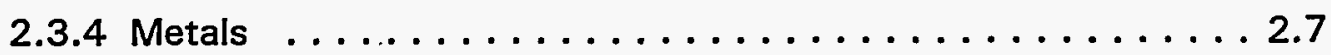

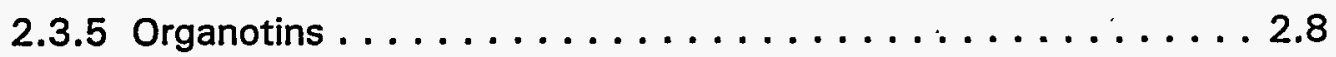

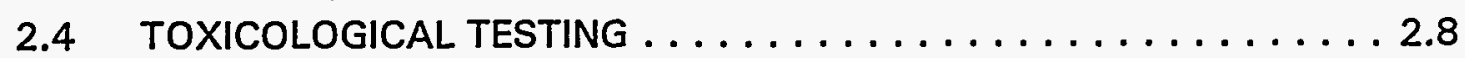

2.4.1 Preparation of Suspended-Particulate-Phase Treatments .. . . . . 2.8

2.4.2 Toxicological Testing Procedures . . . . . . . . . . . . 2.9

2.4.3 Data Analysis and Interpretation ............. 2.13

2.5 QUALITY ASSURANCE/QUALITY CONTROL PROCEDURES $\ldots \ldots .2 .14$

2.5.1 Sample Tracking and Storage . . . . . . . . . . 2.15

2.5.2 Sample and Rinsate Chemistry Quality Control Procedures . . . 2.15

2.5.3 Toxicological Testing Quality Control Procedures . . . . . . . 2.16

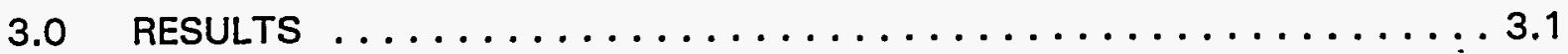

3.1 FIELD COLLECTIONS $\ldots \ldots \ldots \ldots \ldots \ldots \ldots \ldots \ldots \ldots \ldots \ldots$

3.2 SEDIMENT CHEMISTRY $\ldots \ldots \ldots \ldots \ldots \ldots \ldots \ldots \ldots \ldots \ldots \ldots$ 
CONTENTS (contd)

3.2.1 Conventional Measurements . . . . . . . . . . 3.1

3.2.2 Polynuclear Aromatic Hydrocarbons $\ldots \ldots \ldots \ldots \ldots \ldots .2$

3.2.3 Dioxins and Furans $\ldots \ldots \ldots \ldots \ldots \ldots \ldots \ldots \ldots \ldots \ldots \ldots$

3.2.4 Metals $\ldots \ldots \ldots \ldots \ldots \ldots \ldots \ldots \ldots \ldots \ldots \ldots . .5$

3.2.5 Organotins $\ldots \ldots \ldots \ldots \ldots \ldots \ldots \ldots \ldots \ldots \ldots \ldots \ldots \ldots \ldots \ldots$

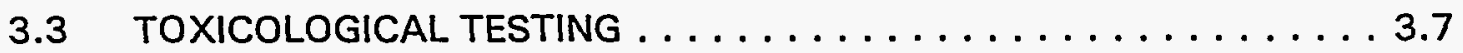

3.3.1 96-Hour Suspended-Particulate-Phase Static Test with

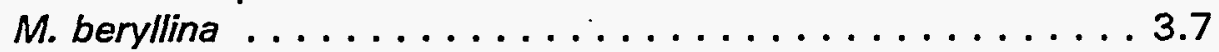

3.3.2 96-Hour Suspended Particulate-Phase Static Test with

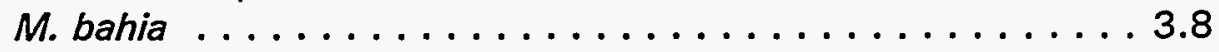

3.3.3 48-Hour Suspended-Particulate-Phase Static Test with

L. pictus . . . . . . . . . . . . . . . . 3.9

4.0 DISCUSSION AND CONCLUSIONS $\ldots \ldots \ldots \ldots \ldots \ldots \ldots \ldots \ldots .1$

4.1 SAMPLE CHEMISTRY $\ldots \ldots \ldots \ldots \ldots \ldots \ldots \ldots \ldots \ldots .1$

4.2 TOXICOLOGICAL TESTING $\ldots \ldots \ldots \ldots \ldots \ldots \ldots \ldots \ldots .2$

4.3 CONCLUSIONS $\ldots \ldots \ldots \ldots \ldots \ldots \ldots \ldots \ldots \ldots \ldots .2$

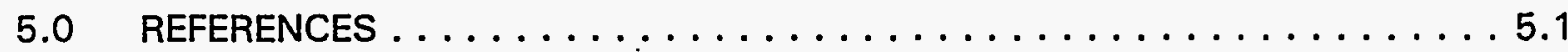

APPENDIX A: SEDIMENT CHEMISTRY DATA AND QUALITY CONTROL

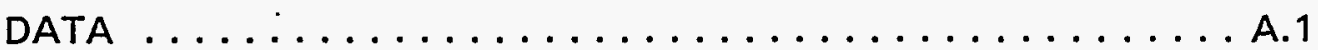

APPENDIX B: RINSATE BLANK CHEMISTRY DATA AND QUALITY CONTROL

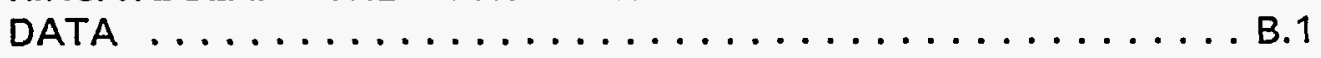

APPENDIX C: $96-$ HOUR $N$. beryllina SUSPENDED-PARTICULATE-PHASE TEST . . C. 1

APPENDIX D: 96-HOUR M. bahia SUSPENDED-PARTICULATE-PHASE TEST . . . . D.1

APPENDIX E: 48-HOUR L: pictus SUSPENDED-PARTICULATE-PHASETEST . . . . E.1 


\section{FIGURES}

2.1 Study Area Map $\ldots \ldots \ldots \ldots \ldots \ldots \ldots \ldots \ldots \ldots \ldots \ldots \ldots \ldots \ldots \ldots \ldots \ldots \ldots .2$

\section{TABLES}

2.1 Analytical Parameters, Analytical Methods, and Target Detection Limits for Sediment and Rinsate Samples . . . . . . . . . . . . . 2.4

2.2 Data Quality Objectives for Sediment and Rinsate Chemistry and

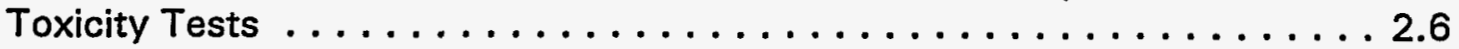

3.1 Summary of Percentage of Solids, Grain Size, and TOC in Sediment Samples 3.2

3.2 Summary of Total LPAH and HPAH, and Total PAH in Sediments and Rinsate Samples . . . . . . . . . . . . . . . . 3

3.3 Summary of Dioxins and Furans in Sediment and Aqueous Samples $\ldots \ldots 3.4$

3.4 Summary of Metals in Sediment and Rinsate Samples ( $\mathrm{Ag}$ to $\mathrm{Hg}$ ) _ . . . 3.5

3.5 Summary of Metals in Sediment and Rinsate Samples (Ni to $\mathrm{Zn}$ ). . . . . . 3.6

3.6 Summary of Organotins in Sediment and Rinsate Samples . . . . . . . . 3.7

3.7 Summary Results for 96-hour Suspended-Particulate-Phase Static Test .

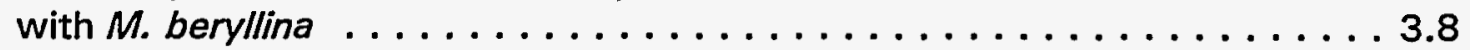

3.8 Summary Results for 96-hour Suspended-Particulate-Phase Static Test

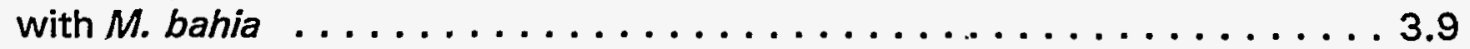

3.9 Summary Results for 48-hour Suspended-Particulate-Phase Static Test

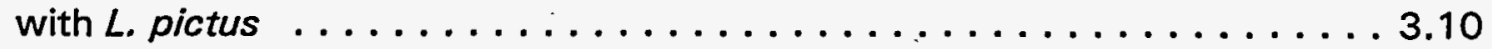




\subsection{INTRODUCTION}

The port of Georgetown, South Carolina, is served by navigational channels within Winyah Bay and the lower Sampit River. Dredging is required to maintain these waterways and to accommodate normal shipping traffic. Prior to dredging, ecological evaluations must be conducted to determine the suitability of the proposed dredged material for openocean disposal. These evaluations are to be performed under Section 103 of the Marine Protection, Research, and Sanctuaries Act of 1972 (MPRSA), following the testing protocols presented in Evaluation of Dredged Material Proposed for Ocean Disposal Testing Manual (USACE/EPA 1991), hereafter known as the 1991 Implementation Manual. In 1992, the Charleston, South Carolina, District of the U.S. Army Corps of Engineers (USACE) requested that Battelle/Marine Sciences Laboratory ${ }^{(2)}$ (MSL) perform physical, chemical, and biological evaluations of the proposed dredged sediments from Winyah Bay and Georgetown Harbor (Ward et al. 1993). The Charleston Intensive Project is a continuation of work from 1992 and reevaluates sediments from the Frazier Point Bend reach of the Winyah Bay channel.

The 1992 evaluations consisted of chemical and physical characterization of sediments from Winyah Bay Entrance Channel, the Winyah Bay Inner Harbor lexcept metals), and the lower Sampit River; toxicity testing of. sediments from the Entrance Channel; and bioaccumulation testing of Inner Harbor sediments. These studies revealed no elevated levels of "contaminants of concern" in Entrance Channel sediments relative to the reference sediments. Chemical parameters for Inner Harbor sediments were not significantly elevated relative to the reference sediments, except for increased levels of polynuclear aromatic hydrocarbons (PAHs) observed in test treatments $\mathrm{IH}-2$ and IH-3. Sampit River stations showed elevated levels of PAHs, metals, and some dioxins. Station SR-1 had elevated levels of Delta-BHC, 4,4'-DDD, and 4,4'-DDE. No benthic or watercolumn toxicity or bioaccumulation potential was demonstrated for any of the sediments tested.

(a) The Battelle/Marine Sciences Laboratory is part of the Pacific Northwest Laboratory, which is operated for the U.S. Department of Energy by Battelle Memorial Institute under Contract DE-AC06-76RLO 1830. 
The current study evaluates sediments from Inner Harbor stations $\mathrm{IH}-2$ and $\mathrm{IH}-3$, as well as from reference site IH-R2, which was outside of the channel. This evaluation consists of testing of physical and chemical parameters, as well as water-column toxicity. The objectives of the Charleston Intensive Project were as follows:

- $\quad$ collect test sediments from stations $\mathrm{IH}-2$ and $\mathrm{IH}-3$, near Frazier Point Bend within Winyah Bay, as well as one reference sediment from station IH-R2 located outside of the navigational channel near Frazier Point. In addition, collect one rinsate water sample. All samples will be sent from the project area to MSL in Sequim, Washington.

- perform physical and chemical evaluations on test and reference sediments, including the aqueous rinsate sample. Physical parameters are sediment grain size and total organic carbon (TOC). Chemical analyses address the U.S. Environmental Protection Agency (EPA) priority pollutants: PAHs, dioxins and furans, metals, and organotins.

- $\quad$ perform water-column toxicity testing on the two test sediments using three sensitive marine species (Menidia beryllina, Mysidopsis bahia, and larval Lytechinus pictus) to determine the acute toxicity of the suspended-particulate phase (SPP) of the proposed dredged material.

This report summarizes the required testing and analysis conducted by MSL to determine the ecological feasibility of the proposed open-ocean disposal of Inner Harbor sediments from the Frazier Bend region. Section 1.0 is the introduction and provides project objectives. Section 2.0 provides the methods and materials used in this study. Section 3.0 presents the results of the physical, chemical, and biological evaluations. Section 4.0 presents a discussion of the results and a summary of the acceptability of the proposed dredged material disposal into the open ocean. Section 5.0 lists the literature cited throughout this document. A series of appendixes contain detailed data listings for the following parts of this study:

Appendix A - Sediment Chemistry Data and Quality Control Data Appendix B - Rinsate Blank Chemistry Data and Quality Control Data Appendix C - 96-Hour N. beryllina Suspended-Particulate-Phase Test Appendix D - 96-Hour M. bahia Suspended-Particulate-Phase Test Appendix E - 48-Hour L. pictus Suspended-Particulate-Phase Test. 


\subsection{MATERIALS AND METHODS}

\subsection{SAMPLE COLLECTION}

Sediment samples were collected from two sites representing the Frazier Point Bend Reach of the Inner Harbor (IH-2 and $\mathrm{IH}-3$ ) on February 1, 1994. Reference sediment was also collected at station IH-R2, just south of Hare Island, for comparison with Inner Harbor sediments. Sediment collection locations are shown in Figure 2.1. All samples were collected by a private contractor. Stations were sampled with a $0.1-\mathrm{m}^{2}$ stainless-steel van Veen grab, which penetrated $8 \mathrm{~cm}$ to $15 \mathrm{~cm}$ into the sediment, depending on sediment type. Sediments were then transferred to solvent-rinsed, acid-cleaned 1-gal glass jars, sealed, and labeled with the study identifier, the station name, and date of collection. A rinsate blank was also collected by rinsing the van Veen grab with distilled water and collecting the rinsate in solvent-rinsed, acid-washed, 1-gal glass jars. All samples were maintained at approximately $4^{\circ} \mathrm{C}$ until they were offloaded, packed with ice-packs, and shipped via overnight air freight to MSL. Upon arrival at MSL, sediment samples were inspected and transferred to a climate-controlled cold-room and maintained at approximately $4^{\circ} \mathrm{C}$ until they were used.

Station positioning was accomplished through the use of LORAN C and visual range markers and was confirmed by water depth observations. Depths were recorded using a calibrated fathometer and corrected to mean lower low water either through the use of a tide gauge or tide table. Formal chain-of-custody procedures were maintained for all samples used in this study.

\subsection{SAMPLE, GLASSWARE, AND EQUIPMENT PREPARATION}

Sediment used for biological testing was prepared and tested within the 6-week holding period, as specified in the 1991 Implementation Manual. During that period, the grab samples were received at MSL and inventoried against chain-of-custody forms, processed for physical and chemical analysis and SPP testing, and used in the biological tests. The following sections describe the preparation of equipment for physical/chemical analyses and SPP tests. 


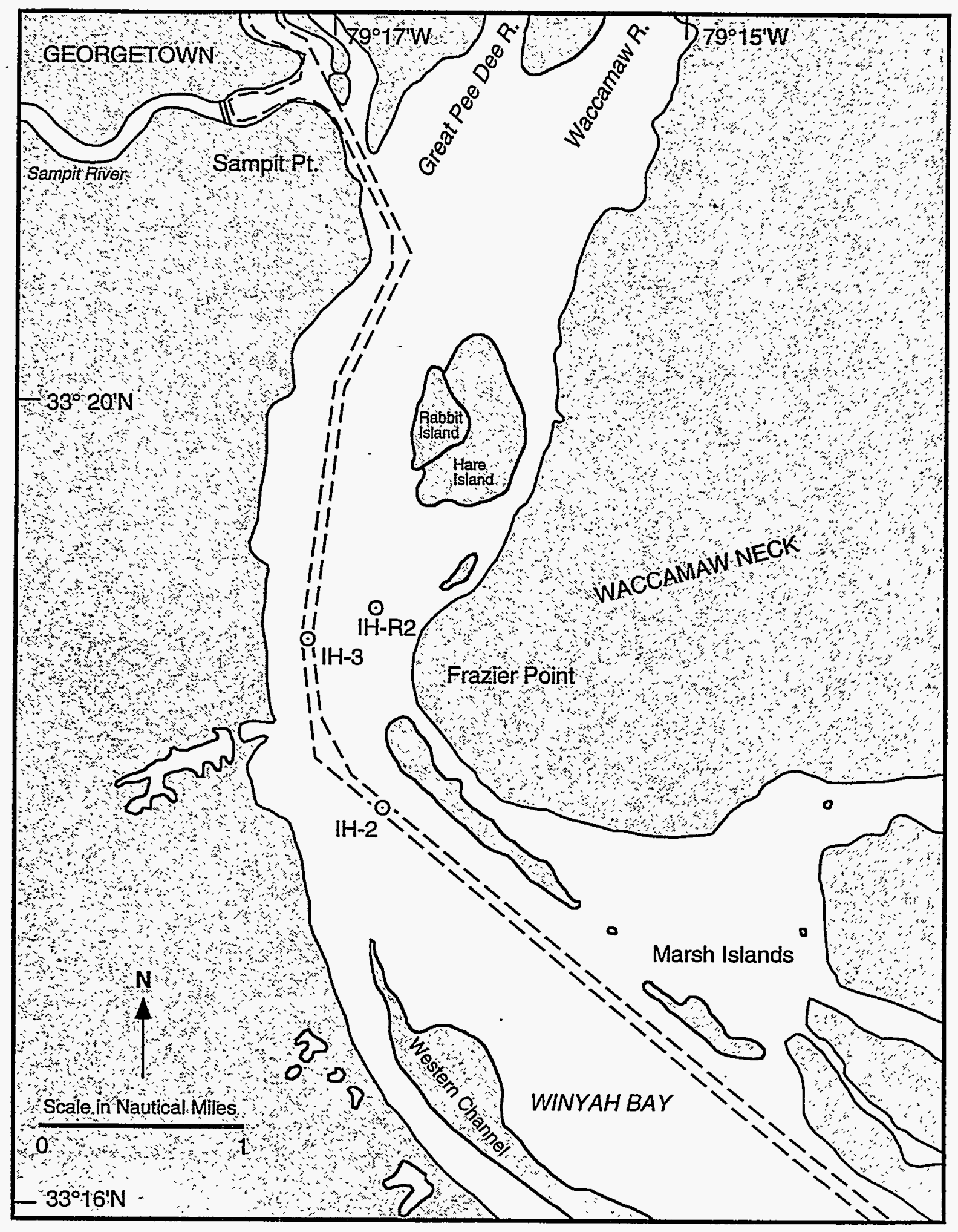

FIGURE 2.1. Study Area Map 
All glassware, stainless-steel utensils, plastic, laboratory containers, and equipment went through stringent cleaning procedures to avoid contaminating sediment samples. Glassware, including test containers and sediment transfer equipment, and items made of polyvinyl chloride (PVC), Nalgene, and other plastics were washed with warm, soapy water, rinsed five times with deionized water, then soaked in a $5 \%$ reagent grade nitric acid bath for a minimum of $4 \mathrm{~h}$. After soaking, the items were rinsed with deionized water five times and allowed to dry.

-Stainless-steel bowls, spoons, spatulas, and other utensils were washed with warm, soapy water, rinsed five times with deionized water, and allowed to air dry. They were then rinsed with methylene chloride under a fume hood and allowed to evaporate dry under the hood before use.

Porous materials were washed with warm, soapy water and rinsed five times with deionized water. These items were then "seasoned" by continuous soaking in, or exposure to, $0.45-\mu \mathrm{m}$-filtered seawater for at least 2 days prior to use.

Equipment used to determine water quality parameters, such as $\mathrm{pH}$, dissolved oxygen (DO), temperature, and salinity, were calibrated according to the manufacturers' specifications and internal MSL procedures.

\subsection{SAMPLE CHEMISTRY PROCEDURES}

Sediment samples and the aqueous rinsate sample collected in support of the Charleston Intensive Program were analyzed for conventional and other chemical parameters. Conventional parameters were grain size and TOC. Sediments were also analyzed for PAHs, dioxins and furans, metals, and butyltins. Table 2.1 presents the analytical parameters measured in sediment and rinsate samples, the method used to perform the analysis, and the target analytical detection limit. 
TABLE 2.1. Analytical Parameters, Analytical Methods, and Target Detection Limits ${ }^{(a)}$ for Sediment and Rinsate Samples

\begin{tabular}{lcc}
\hline \multicolumn{1}{c}{ Analyte } & $\begin{array}{c}\text { Reference } \\
\text { Method }\end{array}$ & $\begin{array}{c}\text { Detection Limit } \\
\text { Sediment,Rinsate }\end{array}$ \\
\hline Grain Size (sediment only) & Plumb 1981 & $1.0 \%$ \\
Total Solids (sediment only) & Plumb 1981 & $1.0 \%$ \\
$\begin{array}{l}\text { Total Organic Carbon } \\
\text { (sediment only) }\end{array}$ & 5310 (APHA 1989) & $0.1 \%$
\end{tabular}

PAHs

Acenapthene

Acenaphthylene

Anthracene

Benzo(a)anthracene

Benzo(a)pyrene

Benzo(b)fluoranthene

Benzo(g,h,i)perylene

Benżo(k)fluoranthene

Chrysene

Dibenzo(a,h)anthracene

Fluoranthene

Fluorene

Indeno(1,2,3-cd)pyrene

Napthalene

Methlynapthalene

Phenanthrene

Pyrene
8270 (EPA 1986)

8270 (EPA 1986)

8270 (EPA 1986)

8270 (EPA 1986)

8270 (EPA 1986)

8270 (EPA 1986)

8270 (EPA 1986)

8270 (EPA 1986)

8270 (EPA 1986)

8270 (EPA 1986)

8270 (EPA 1986)

8270 (EPA 1986)

8270 (EPA 1986)

8270 (EPA 1986)

8270 (EPA 1986)

8270 (EPA 1986)

8270 (EPA 1986)

8290 (EPA 1990a)

All congeners

Metals

Arsenic

Cadmium

Chromium

Copper

Lead

Mercury

Nickel

Selenium

Silver

Zinc

\section{Butyltins}

Monobutyltin

Dibutyltin

Tributyltin
Unger et al. (1986) Unger et al. (1986)

Unger et al. (1986)
ICP/MS (EPA 1990b)

GFAA (EPA 1986)

ICP/MS (EPA 1990b), GFAA (EPA 1986)

ICP/MS (EPA 1990b)

ICP/MS(EPA 1990b)

CVAA (EPA 1986)

ICP/MS (EPA 1990b)

ICP/MS (EPA 1990b)

GFAA (EPA 1986)

ICP/MS (EPA 1990b)
$30 \mu \mathrm{g} / \mathrm{kg}, 2000 \mathrm{ng} / \mathrm{L}$ $30 \mu \mathrm{g} / \mathrm{kg}, 2000 \mathrm{ng} / \mathrm{L}$ $30 \mu \mathrm{g} / \mathrm{kg}, 2000 \mathrm{ng} / \mathrm{L}$ $30 \mu \mathrm{g} / \mathrm{kg}, 2000 \mathrm{ng} / \mathrm{L}$ $30 \mu \mathrm{g} / \mathrm{kg}, 2000 \mathrm{ng} / \mathrm{L}$ $30 \mu \mathrm{g} / \mathrm{kg}, 2000 \mathrm{ng} / \mathrm{L}$ $30 \mu \mathrm{g} / \mathrm{kg}, 2000 \mathrm{ng} / \mathrm{L}$ $30 \mu \mathrm{g} / \mathrm{kg}, 2000 \mathrm{ng} / \mathrm{L}$ $30 \mu \mathrm{g} / \mathrm{kg}, 2000 \mathrm{ng} / \mathrm{L}$ $30 \mu \mathrm{g} / \mathrm{kg}, 2000 \mathrm{ng} / \mathrm{L}$ $30 \mu \mathrm{g} / \mathrm{kg}, 2000 \mathrm{ng} / \mathrm{L}$ $30 \mu \mathrm{g} / \mathrm{kg}, 2000 \mathrm{ng} / \mathrm{L}$ $30 \mu \mathrm{g} / \mathrm{kg}, 2000 \mathrm{ng} / \mathrm{L}$ $30 \mu \mathrm{g} / \mathrm{kg}, 2000 \mathrm{ng} / \mathrm{L}$ $30 \mu \mathrm{g} / \mathrm{kg}, 2000 \mathrm{ng} / \mathrm{L}$ $30 \mu \mathrm{g} / \mathrm{kg}, 2000 \mathrm{ng} / \mathrm{L}$ $30 \mu \mathrm{g} / \mathrm{kg}, 2000 \mathrm{ng} / \mathrm{L}$

$1.0 \mathrm{ng} / \mathrm{kg}, 1.0 \mathrm{ng} / \mathrm{L}$

$0.1 \mathrm{mg} / \mathrm{kg}, 2.5 \mu \mathrm{g} / \mathrm{L}$ $0.1 \mathrm{mg} / \mathrm{kg}, 0.1 \mu \mathrm{g} / \mathrm{L}$ $0.6 \mathrm{mg} / \mathrm{kg}, 33 \mu \mathrm{g} / \mathrm{L}$ $0.1 \mathrm{mg} / \mathrm{kg}, 5.5 \mu \mathrm{g} / \mathrm{L}$ $0.1 \mathrm{mg} / \mathrm{kg}, 6.2 \mu \mathrm{g} / \mathrm{L}$ $0.01 \mathrm{mg} / \mathrm{kg}, 0.01 \mu \mathrm{g} / \mathrm{L}$ $0.1 \mathrm{mg} / \mathrm{kg}, 7.5 \mu \mathrm{g} / \mathrm{L}$ $0.3 \mathrm{mg} / \mathrm{kg}, 0.2 \mu \mathrm{g} / \mathrm{L}$ $0.1 \mathrm{mg} / \mathrm{kg}, 0.02 \mu \mathrm{g} / \mathrm{L}$ $0.3 \mathrm{mg} / \mathrm{kg}, 7.8 \mu \mathrm{g} / \mathrm{L}$
$10 \mu \mathrm{g} / \mathrm{kg}, 10 \mu \mathrm{g} / \mathrm{L}$ $10 \mu \mathrm{g} / \mathrm{kg}, 10^{\circ} \mu \mathrm{g} / \mathrm{L}$ $10 \mu \mathrm{g} / \mathrm{kg}, 10 \mu \mathrm{g} / \mathrm{L}$

(a) Detection limits are in dry weight for all sediment parameters. Detection limits are in wet weight for all organic tissue parameters. 
The following sections briefly describe the methods used for analysis of sediments and rinsate samples for the required physical and chemical parameters. Analyses followed established EPA procedures where applicable. Quality control $(\mathrm{QC})$ samples consisted of method blanks, matrix spike (MS) and matrix spike duplicate (MSD) analyses, standard reference materials (SRMs), and analytical replicates. The MS, MSD, and SRMs were used as a measurement of analytical accuracy. The analytical replicates, MS, and MSD were used to evaluate analytical precision. Data quality objectives for each analysis are summarized in Table 2.2.

\subsubsection{Conventional Measurements}

Conventional, or physical, parameters measured were grain size, total solids, and TOC. Grain size and percentage of solids analysis was conducted by Soil Technology of Bainbridge Island, Washington, and followed the procedures described in Plumb (1981). Seventeen grain-size fractions (expressed in microns) were quantified: $4750,2000,850$, $425,250,149,75,62.5,48,31.2,23,15.6,7.8,3.9,1.9$, and $\leq 0.9$. These data are reported as "apparent" grain size, because organic material is included in the analysis. Analysis of TOC was performed by. Global Geochem in Canoga Park, California, following Method 9060 (APHA 1989). TOC is the amount of nonvolatile, partially volatile, volatile, and particulate organic carbon in a sample. Each sediment treatment was dried and ball-milled to a fine powder. Before combustion, inorganic carbon in the sample was removed by acidification. The TOC in sediment was then determined by measuring the carbon dioxide released during combustion of the sample and reported as a percentage of dry weight.

\subsubsection{Polynuclear Aromatic Hydrocarbons}

Analyses for 17 PAHs in the Inner Harbor sediment and rinsate samples were performed by the Battelle Ocean Sciences Laboratory in Duxbury, Massachusetts. Analysis of these compounds followed EPA-SW-846 Method 8270 (EPA 1986). Sediment and water samples were extracted two to three times consecutively using a roller technique. The extracts were dried with sodium sulfate, passed through a cleanup column, and concentrated in preparation for further cleanup by liquid chromatography. PAHs in sample extracts were analyzed via high-resolution capillary gas chromatography/mass spectrophotometry (GC/MS). A data system provided for the identification and 


\section{TABLE 2.2 Data Quality Objectives for Sediment and Rinsate Chemistry and Toxicity Tests}

\begin{tabular}{|c|c|c|c|}
\hline Parameter & QC Measurement & Frequency & Acceptable Limits \\
\hline Organics $^{(a)}$ & $\begin{array}{l}\text { Procedural blank } \\
\text { Surrogate internal standards (SIS) } \\
\text { Matrix spike/matrix spike duplicate (MS/MSD) } \\
\text { Standard reference material }\end{array}$ & $\begin{array}{c}1 \\
\text { Each sample } \\
1 \\
1\end{array}$ & $\begin{array}{l}<\mathrm{MDL} \\
40 \%-120 \% \%^{(b)} \\
40 \%-120 \% \%^{(b)} \\
\leq 30 \%\left({ }^{(c)} \text { between MS/MSD }\right. \\
\leq 30 \%{ }^{(\mathfrak{)})} \text { from certified value }\end{array}$ \\
\hline Metals ${ }^{(0)}$ & $\begin{array}{l}\text { Method blank } \\
\text { Matrix spike } \\
\text { Laboratory duplicates } \\
\text { Standard reference material }\end{array}$ & $\begin{array}{l}1 \\
1 \\
1 \\
1\end{array}$ & $\begin{array}{l}<\mathrm{DL} \times 3 \\
75 \%-125 \%^{(b)} \\
\leq 20 \% \%^{(\mathrm{c})} \\
\leq 30 \%^{(\mathrm{d})} \text { from certified value }\end{array}$ \\
\hline $\begin{array}{l}\text { Conventionals }^{(0)} \\
\text { Grain Size } \\
\text { Total Organic Carbon } \\
\text { Total Solids }\end{array}$ & $\begin{array}{l}\text { Laboratory duplicates } \\
\text { Standard Reference Material } \\
\text { Laboratory duplicates }\end{array}$ & $\begin{array}{l}1 \text { per } 10 \text { samples } \\
1 \text { per } 20 \text { samples } \\
1 \text { per } 10 \text { samples }\end{array}$ & $\begin{array}{l}\leq 20 \%^{(c)} \\
\leq 20 \%^{(d)} \text { from established value } \\
\leq 20 \%^{(c)}\end{array}$ \\
\hline $\begin{array}{l}\text { Toxicity Tests } \\
\text { Suspended-Particulate- } \\
\text { Phase Tests (Non-Larval) } \\
\text { Suspended-Particulate- } \\
\text { Phase Test (Larvae) }\end{array}$ & $\begin{array}{l}0 \% \text { Control } \\
0 \% \text { Control }\end{array}$ & $\begin{array}{l}\text { Concurrent with each test } \\
\text { Concurrent with each test }\end{array}$ & $\begin{array}{l}\leq 10 \% \text { mortality } \\
\leq 30 \% \text { mortality }\end{array}$ \\
\hline $\begin{array}{l}\text { (a) Applies to sediments and rinsate; c } \\
\text { (o) Percentage of recovery. } \\
\text { (c) Relative percentage difference (RP } \\
\text { (d) Percentage difference (PD). } \\
\text { (o) Applies to sediments and rinsate; } \\
\text { (1) Applies to sediments only. }\end{array}$ & $\begin{array}{l}\text { organics are PAHs, butyltins, dioxins. } \\
\text { M). } \\
\text { Metals: } \mathrm{Ag}, \mathrm{As}, \mathrm{Cd}, \mathrm{Cr}, \mathrm{Cu}, \mathrm{Hg}, \mathrm{Ni}, \mathrm{Pb}, \mathrm{Se}, \mathrm{Zn} \text {. }\end{array}$ & 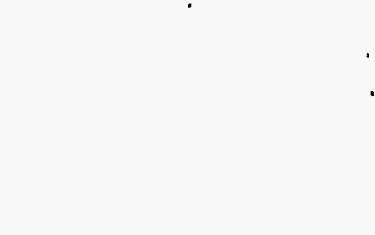 & \\
\hline
\end{tabular}


measurement of the selected PAHs in a selective ion monitoring (SIM) mode. In the SIM mode, each PAH compound was monitored simultaneously for the presence of a parent ion and a confirming second ion.

\subsubsection{Dioxins and Furans}

Dioxin and furan analysis in sediment and rinsate samples was performed by Battelle Memorial Institute in Columbus, Ohio, following the procedures summarized in EPA-SW-846, Method 8290 (EPA 1990a). This analytical method uses high-resolution gas chromatography and high-resolution mass spectrometry (HRGC/HRMS) on purified sample extracts. Samples are spiked with a solution containing nine isotopically labeled polychlorinated benzodioxins and dibenzofuran (PCDD/PCDF) compounds, and extracted according to a matrix-specific procedure. Sediment samples undergo a toluene or benzene Soxhlet extraction; water samples undergo a hexane/methylene chloride Soxhlet extraction. The extracts are subjected to an acid-base washing and then dried. Following a solventexchange step, the residues are cleaned up by column chromatography and are spiked with ${ }^{13} \mathrm{C}_{12}-1,2,3,4$-tetra-chlorodibenzodioxin (TCDD) to determine percentage recoveries of tetraand pentachloronated PCDD/PCDF congeners, and with ${ }^{13} \mathrm{C}_{12}-1,2,3,7,8,9$-hexa-CDD to determine percentage recoveries of hexa-, hepta-, and octachloronated PCDD/PCDF congeners. The extracts are injected into a HRCG/HRMS system capable of performing in the SIM mode. Significant revisions to Method 8290 are as follows:

- Use additional ${ }^{13} \mathrm{C}_{12}$-labeled internal standards so that each 2,3,7,8-substituted PCDD/PCDF isomer can be related to an internal standard for identification and quantification purposes. Use of a complete range of internal standards provides better accuracy than is afforded by current Method 8290 procedures.

- Use ${ }^{37} \mathrm{C}_{14}$-labeled 2,3,7,8-tetra-CDD as a cleanup recovery standard. This cleanup recovery standard is added to sample extracts prior to cleanup to evaluate analyte recovery through cleanup procedures. Procedures similar to EPA Method 1613 are followed for this cleanup recovery standard. This cleanup recovery standard provides an additional measure of quality control.

- Routinely calibrate only at the beginning of the analytical period rather than at the beginning and end of the analytical period. This does not appear to affect data quality.

\subsubsection{Metals}

Metals in the sediment and rinsate samples were analyzed at MSL. Three techniques were used for the analysis of sediment as follows: inductively coupled 
plasma/mass spectroscopy (ICP/MS), graphite furnace atomic absorption (GFAA), and cold vapor atomic absorption (CVAA). The ICP/MS technique follows procedures summarized in the EPA 200.8 (EPA 1990b) and is used for analyzing arsenic (As), chromium (Cr), copper $(\mathrm{Cu})$, lead $(\mathrm{Pb})$, nickel ( $\mathrm{Ni})$, selenium (Se), and zinc $(\mathrm{Zn})$. The GFAA method is summarized in EPA-SW-846, 7000 Series, which was adapted into MSL Standard Operating Procedure MSL-M-033. This method was used for cadmium (Cd) and silver (Ag) analyses. The CVAA method for analyzing mercury $(\mathrm{Hg})$ is summarized in EPA-SW-846, 7000 series which was adapted into a MSL standard operating procedure.

To prepare sediment for analysis, samples were freeze-dried and blended in a Spex mixer-mill. Approximately $5 \mathrm{~g}$ of mixed sample was ground in a ceramic ball mill. For ICP/MS, GFAA, and CVAA analyses, 0.2- to 0.5-g aliquots of dried, homogenous sample went through an acid digestion process to separate and isolate the metals from the matrix.

\subsubsection{Organotins}

Organotins in sediment and rinsate were analyzed at MSL. Butyltin compounds in sediment and rinsate were analyzed using gas chromatography/flame photometric detection (GC/FPD), following the methods of Unger et al. (1986).

Wet samples were extracted with methylene chloride and tropolone. Propyltin was added before extraction as a surrogate compound to assess extraction efficiency. The mono-, di-, tri-, and tetrabutyltin compounds extracted from the sediment and rinsate were derivatized to a less volatile, more thermally stable form (nonionic n-hexyl/or n-pentyl derivatives).

The extracts were passed through a Florisil liquid chromatography column for cleanup, and the butyltins were quantified by GC/FPD.

\subsection{TOXICOLOGICAL TESTING}

\subsubsection{Preparation of Suspended-Particulate-Phase Treatments}

The SPP of test sediment samples was used to evaluate water-column effects of open-water dredged material disposal. The SPP is the liquid that remains after intermixing sediment with seawater and allowing heavier particles to settle to the bottom. Because SPP preparation does not involve filtration, this phase contains suspended particles as well 
as dissolved constituents. The SPP tests evaluate effects caused by both the physical presence of the suspended particles and the chemical toxicity of contaminants associated with the particles or dissolved fractions. The process is intended to approximate exposure conditions created as a result of materials being discharged through the water column during dredged-disposal operations.

The first step of SPP preparation was to create a 4:1 (volume:volume) water to sediment slurry in 1-L glass jars with Teflon-lined lids. The jars were marked at $200 \mathrm{~mL}$ and $400 \mathrm{~mL}$ increments. Seawater was added to the 200-mL mark, and homogenized sediment was added until the water was displaced to the $400-\mathrm{mL}$ mark; then the jar was filled to $1 \mathrm{~L}$ with filtered seawater. A set of 12 jars containing sediment and water was placed on a shaker table and agitated for $30 \mathrm{~min}$ at a rate of 120 to $150 \mathrm{cycles} / \mathrm{min}$. After shaking, thie slurry was poured into $500-\mathrm{mL}$ Teflon containers with tightly fitted lids, which were then placed in a centrifuge and spun for $15 \mathrm{~min}$ at approximately $1750 \mathrm{rpm}$. The $15-$ min centrifugation was necessary to ensure that test organisms would be visible at the first observation after exposure to SPP test treatments. After centrifugation, the supernatant was poured into a clean, 1-gal glass jar for use in the SPP tests; the remaining sludge mixture was discarded. If SPP was not used immediately, it was stored at $4^{\circ} \mathrm{C}$ for no more than $24 \mathrm{~h}$.

\subsubsection{Toxicological Testing Procedures}

The SPP tests were used to assess the potential effects of discharging dredged material through the water column during disposal operations. The SPP tests evaluate 1) effects caused by the physical presence of suspended particles, 2) toxicity of chemical contaminants associated with the particles, and 3) the toxicity of chemical contaminants dissolved into the water column. Three SPP tests were conducted: a $96-h$, static exposure utilizing the silverside, $M$. beryllina; a 96-h, static exposure using the mysid, M. bahia; and a 48-h, static exposure of larvae of the urchin, L. pictus. The SPP treatments were prepared as described in Section 2.4.1. For each SPP treatment, there were five replicates at each concentration: $0 \%$ (seawater), 10\%, 50\%, and 100\% (SPP). All test containers were placed in random positions on the water tables. Since the SPP test evaluated the difference in test organism response between the SPP exposures and a $0 \%$ seawater control, the testing of reference sediment was not required. 


\section{6-Hour SPP Static Test with M. beryllina}

Seven-day-old $M$. beryllina were received from Aquatic Indicators Inc., St. Augustine, Florida. The silversides were held prior to testing in a flow-through, 10-gal glass aquarium and fed <24-h-old brine shrimp nauplii (Artemia salina) twice daily. Temperature, $\mathrm{pH}, \mathrm{DO}$, and salinity of water in the aquarium were monitored daily. This test was conducted between February 25 and March 1, 1994.

This 96-h, static SPP test was conducted in 1-qt Mason jars filled to a total volume of $500 \mathrm{~mL}$. Dilutions of $0 \%, 10 \%, 50 \%$ and $100 \%$ SPP were prepared with $0.45-\mu \mathrm{m}$ filtered Sequim Bay seawater. Five replicate jars of each test concentration were placed onto a $20^{\circ} \mathrm{C}$ water table and provided with gentle aeration. The test was conducted under a 16-h light, 8-h dark regime. Once the test treatments had reached test temperature $\left(20^{\circ} \mathrm{C}\right)$, initial water quality parameters were measured and the test initiated.

The test was initiated by adding ten 11-day-old $M$. beryllina to each test container. The fish were gently pipetted from the holding tank into clean seawater and counted into small transfer containers. The number of organisms was then confirmed by a second observer before the fish were placed into the test container. The date and time of initiation were recorded on data forms and on the lids of the test containers. M. beryllina were observed daily during the test, and the number of live and dead organisms was noted on the data forms. Dead animals were removed daily. Water temperature, salinity, pH, and DO were measured daily in one replicate of each sediment treatment and in all containers at initiation and termination of the test. Acceptable ranges for water quality parameters during the experiment were as follows:

$\begin{array}{ll}\text { DO } & \geq 4.0 \mathrm{mg} / \mathrm{L} \\ \text { pH } & \text { ambient } \pm 0.5 \text { units } \\ \text { Salinity } & 30 \mathrm{ppt} \pm 2.0 \mathrm{ppt} \\ \text { Temperature } & 20^{\circ} \mathrm{C} \pm 2.0^{\circ} \mathrm{C} .\end{array}$

At the end of the test $(96 \mathrm{~h})$, final observations were conducted. The endpoint of this test was death, defined as the absence of movement in response to gentle probing. At least $10 \%$ of the mortality counts were confirmed by a second observer. Test organism sensitivity was assessed through a $96-\mathrm{h}$ reference toxicant test, which included a seawater 
control and four concentrations of copper $\left(4,16,64,160\right.$, and $\left.400 \mu \mathrm{g} / \mathrm{L} \mathrm{CuSO}_{4}\right)$. This test was conducted in the same manner as were the SPP tests.

\section{6-Hour SPP Static Test with M. bahia}

One-day-old $M$. bahia were received from Aquatic Indicators and were held prior to testing in a flow-through, 10 -gal glass aquarium and fed $<24$-h-old brine shrimp nauplii (Artemia salina) twice daily. Temperature, $\mathrm{pH}, \mathrm{DO}$, and salinity of water in the aquarium were monitored daily. The 4-day mysid test was conducted between March 4 and March 8, 1994.

This 96-h static SPP test was conducted in 500-mL glass jars filled to a total volume of $300 \mathrm{~mL}$. Dilutions of $0 \%, 10 \%, 50 \%$ and $100 \%$ SPP were prepared with $0.45-\mu \mathrm{m}$-filtered Sequim Bay seawater. Five replicate jars of each test concentration were placed onto a $20^{\circ} \mathrm{C}$ water table and provided with gentle aeration. The test was conducted under a 16-h light, 8 -h dark regime. Once the test treatments had reached test temperature $\left(20^{\circ} \mathrm{C}\right)$, initial water quality parameters were measured and the test initiated.

The test was initiated by adding ten 4-day-old $M$. bahia to each test container. The mysids were gently netted from the holding tank into clean seawater and pipetted into small transfer containers. The number of organisms was then confirmed by a second observer before mysids were transferred into the test container. The date and time of initiation were recorded on data forms and the lids of the test containers. $M$. bahia were observed daily during the test, and the number of live and dead organisms was noted on the data forms. Dead animals were removed daily. Water temperature, salinity, $\mathrm{pH}$, and DO were measured daily in one replicate of each sediment treatment and in all containers at initiation and termination of the test. Acceptable ranges for water quality parameters during the experiment were as follows:

$\begin{array}{ll}\text { DO } & \geq 4.0 \mathrm{mg} / \mathrm{L} \\ \text { pH } & \text { ambient } \pm 0.5 \text { units } \\ \text { Salinity } & 30 \mathrm{ppt} \pm 2.0 \mathrm{ppt} \\ \text { Temperature } & 20^{\circ} \mathrm{C} \pm 2.0^{\circ} \mathrm{C} .\end{array}$

At the end of the test $(96 \mathrm{~h})$, final observations were conducted. The endpoint of this test was death, defined as the absence of movement in response to gentle probing. At least $10 \%$ of the mortality counts were confirmed by a second observer. Test organism 
sensitivity was assessed through a 96-h reference toxicant test, which included a seawater control and four concentrations of copper $\left(50,100,150\right.$, and $\left.300 \mu \mathrm{g} / \mathrm{L} \mathrm{CuSO}_{4}\right)$. This test was conducted in the same manner as were the SPP tests.

\section{8-Hour SPP Static Test with L. pictus}

Adult $L$. pictus were received from Marinus Inc. and used for testing on the day of receipt. The 48-h larval test was conducted between February 13 and February 15, 1994. Test chambers for the urchin larvae test were $400-\mathrm{mL}$ glass jars with a $300 \mathrm{~mL}$ test volume. Dilutions of $0 \%, 10 \%, 50 \%$, and $100 \%$ SPP were prepared with $0.45-\mu \mathrm{m}$ filtered Sequim Bay seawater. Five replicate jars of each test concentration were placed randomly onto a $20^{\circ} \mathrm{C}$ water table and provided with gentle aeration. The light regime for this test was $16 \mathrm{~h}$ light and $8 \mathrm{~h}$ dark. Once the containers had reached test temperature $\left(20^{\circ} \mathrm{C} \pm 2^{\circ} \mathrm{C}\right)$, initial water quality parameters were measured in all replicates.

Adult $L$. pictus were induced to spawn by injection approximately $1 \mathrm{~mL}$ of $0.5-\mathrm{M}$ potassium chloride into the coelomic cavity through the peristomal membrane. Females were placed in seawater-filled beakers and allowed to shed their yellow eggs directly into seawater. Sperm, appearing white, was collected directly from the male urchins and kept "dry" until needed for fertilization. After spawning was completed (approximately $30 \mathrm{~min}$ ), eggs from individual females were passed through a 75- $\mu \mathrm{m}$ Nytex screen into separate glass jars. A sperm solution was prepared with approximately $1 \mathrm{~mL}$ of concentrated sperm pooled from several males mixed with $45 \mathrm{~mL}$ of filtered seawater. Approximately $10 \mathrm{~mL}$ of the sperm stock was introduced to the egg solution from each female. Fertilization was allowed to take place for $90 \mathrm{~min}$, at which time fertilization rate was examined. Egg stocks with greater than $90 \%$ multiple cell embryos were used in the test. Eggs were pooled and filtered on a $20-\mu \mathrm{m}$ Nytex screen to rinse away excess sperm. The eggs were rinsed from the $20-\mu \mathrm{m}$ screen into a clean container and diluted with seawater.

To estimate fertilization success and embryo density, a $0.1-\mathrm{mL}$ subsample was removed from the stock solution and the number of developing embryos scored using a Sedgewick-Rafter counting chamber on a compound microscope at low magnification. The mean number of embryos from the replicate counts was multiplied by 10 to reflect the density of embryos in the embryo stock (embryos $/ \mathrm{mL}$ ). 
To initiate the test, an appropriate amount of urchin embryo stock solution was pipetted into each test container to yield a density of 25 to $30 \mathrm{embryos} / \mathrm{mL}$. A perforated plunger was used to thoroughly mix the contents of the stock container before removing each aliquot with a micropipette. The test initiation date and time were recorded on data record forms. A $10-\mathrm{mL}$ subsample was collected from each test chamber with a micropipette and placed in a labeled vial, fixed with $1 \mathrm{~mL}$ of $50 \%$ Formalin, and scored for the number of fertilized eggs. These counts were used to determine stocking density.

Water quality parameters were measured in one replicate of each dilution $24 \mathrm{~h}$ after test initiation. Acceptable ranges for water quality parameters during the experiment were as follows:

$\begin{array}{lll}\text { DO } & & \geq 4.0 \mathrm{mg} / \mathrm{L} \\ \text { pH } & \ldots & \text { ambient } \pm 0.5 \text { units } \\ \text { Salinity } & & 30 \mathrm{ppt} \pm 2.0 \mathrm{ppt} \\ \text { Temperature } & & 20.0^{\circ} \mathrm{C} \pm 2.0^{\circ} \mathrm{C} .\end{array}$

The urchin test was terminated after $48 \mathrm{~h}$, when $90 \%$ of the embryos observed in the controls had reached the pluteus stage. Each chamber was then homogenized with the perforated plunger, and a 10-mL aliquot was removed with a calibrated micropipette and placed in a labeled vial containing $1 \mathrm{~mL}$ of $50 \%$ Formalin. Samples were scored for the appearance of normal pluteus larvae, abnormally developed pluteus larvae, and an "other" category, which included developmentally delayed larvae, as well as abnormal nonpluteus larvae. At least $10 \%$ of the counts were confirmed by a second observer. Test organism sensitivity was assessed through a 48-h reference toxicant test, which included a seawater control and four concentrations of copper $\left(3,9,30\right.$, and $\left.100 \mu \mathrm{g} / \mathrm{L} \mathrm{CuSO}_{4}\right)$. This test was conducted in the same manner as were the SPP tests.

\subsubsection{Data Analysis and Interpretation}

Several statistical analyses were conducted to determine the magnitude and significance of toxicity in test treatments relative to seawater controls. Each statistical test was based on a completely random design that allowed unbiased comparison among treatments. Test design and specific statistical analysis procedures are discussed in this section. 
All SPP toxicity tests were designed as completely random tests. Organisms were randomly allocated to all concentrations of each treatment, and treațents were randomly positioned on water tables. To determine the randomization, a random-number table was generated for each toxicity test using the discrete uniform random-number generator in the LOTUS 123 spreadsheet software.

Two statistical tests are presented in the 1991 Implementation Manual for the interpretation of SPP tests. The first test is a two-sided t-test comparing survival in control replicates and in the $100 \%$ SPP replicates. This test is performed only when survival in the $100 \%$ SPP is less than control (O\% SPP) survival and when control survival is greater than $90 \%$ (indicating test validity). Prior to conducting the $t$-test, angular transformation (arcsine of the square root) of the proportion surviving in test replicates is performed to reduce possible heterogeneity of variance between control and $100 \%$ SPP mean survivals. The second test required by the 1991 Implementation Manual is an LC $_{50}$ calculation, the concentration of SPP that is lethal to $50 \%$ of the individuals tested. The LC $_{50}$ values for these tests were calculated using the Trimmed Spearman-Karber Method (Finney 1971). The Spearman-Karber estimator is appropriate only if there is increasing mortality with increasing concentration and if $50 \%$ or greater mortality is observed in test solutions when normalized to control survival. If $50 \%$ mortality does not occur in the $100 \%$ SPP dilutions for any treatments, then $L_{50}$ values are reported as $>100 \%$ SPP. The same method was

used to calculate $\mathrm{EC}_{50}$ values (the concentration at which $50 \%$ of the test individuals show a certain effect) for the urchin SPP test and $L_{50}$ values $\left(\mathrm{LC}_{50}\right.$ and $\mathrm{EC}_{50}$ for $L$. pictus) for all reference toxicant tests.

\subsection{QUALITY ASSURANCE/QUALITY CONTROL PROCEDURES}

The quality assurance/quality control $(\mathrm{QA} / \mathrm{OC})$ procedures followed for these studies were consistent with the 1991 Implementation Manual and the recommended protocols (PSEP 1986). The procedures followed were documented by Pacific Northwest Laboratory (PNL) Quality Engineering Division as a QA Plan. A member of PNL's quality engineering staff was present throughout each phase of these studies to ensure that accepted procedures were followed. Daily logs were assigned to each portion of the study and served as records of day-to-day activities during the research. All entries in the daily log 
were initialed, dated, and reviewed by both the project manager and the quality assurance engineer: The following discussion summarizes $Q A / O C$ procedures followed for the three main portions of this study: sediment sampling, biological testing, and chemical testing (all QA/QC evaluations are contained in Volume 2, Appendix Cl.

\subsubsection{Sample Tracking and Storage}

All samples were accompanied by chain-of-custody forms from the time of collection to receipt at MSL. After sample selection, a new set of custody forms was initiated for the sediment subsamples requiring chemical analyses. These accompanied the samples to the appropriate laboratory for chemical analysis, where the forms were signed and returned to the MSL project manager.

All sediment collected for these studies was stored in glass containers. Subsamples for chemical analyses were obtained prior to biological testing. These subsamples were stored frozen until chemical analyses were performed. Samples for organic analyses were stored frozen for up to 2 months (PSEP 1986). Samples for metals were freeze-dried upon receipt at the laboratory and held for up to 6 months (PSEP 1986; EPA/USACE 1991). Sediment grab samples. were stored at $4^{\circ} \mathrm{C}$ prior to biological testing. .

\subsubsection{Sediment and Rinsate Chemistry Quality Control Procedures}

Chemical testing procedures require that specific QA/QC protocols be followed; QA/QC guidelines specific to this project are provided in the PNL Quality Assurance Division as a QA Plan. These guidelines include the following:

- $\quad$ analysis of a method blank with each batch of samples

- analysis of matrix spikes on $20 \%$ of the samples (where applicable) with appropriate compounds to assess accuracy

- duplicate analyșis on at least $10 \%$ of the samples to assess analytical precision

- analysis of at least one SRM, if available for the analytes of interest and sample matrix

- $\quad$ archiving of all instrument printouts (e.g., raw data and chromatograms from atomic absorption [AA] and gas chromatography [GC] analyses) for future review. 
In actual practice, some of the specific guidelines listed in the QA Plan for analytical precision and accuracy were modified to apply to the most current methods employed by laboratories. The guidelines for detection limits, range of recovery, and relative precision are listed in the Winyah Bay QA Plan provided to USACE by MSL.

Measurements of accuracy can be determined by analyzing MSs of known concentrations and standard reference materials that have been certified for the presence of specific parameters. The MSs were analyzed for PAHs and organotins; they generally made up a subset of the analytes of interest. Percentage recoveries were calculated based on the differences between the amount spiked and the amount recovered in the sample. One MS was included in PAH analysis, whereas one MS and one MSD were analyzed for organotins. Analytical accuracy was measured through the analysis of SRMs. In sediment and rinsate samples, SRMs were analyzed for metals and organic compounds.

Surrogate compounds were added in known amounts to samples analyzed for PAHs, dioxins, and butyltins. Surrogate compounds are added to samples prior to extraction, and their recoveries are a measurement of the efficiency or procedural accuracy of the analysis.

Measurements of precision were obtained through replicate analysis of selected sediment treatments. The measurements of precision are the industrial statistic (l-stat) and relative percentage difference (RPD) for duplicate analyses. The I-stat is defined as the absolute value of the difference between duplicate measurements divided by the sum of the duplicates. The RPD is defined as the absolute value of the difference between two duplicate measurements, divided by the mean of the duplicates, multiplied by 100 . All instrument printouts and other raw data generated using MSL analytical instruments are filed at MSL for future reference. Procedures and related data were written into the appropriate daily log. Copies of data generated by offsite analytical facilities are maintained at MSL.

\subsubsection{Toxicological Testing Quality Control Procedures}

Appropriate procedures for organism care were maintained from animal receipt through testing. Organisms shipped to MSL were gradually equilibrated to ambient conditions. Animals were fed, if necessary, before biological testing. 
During testing, water quality parameters were measured to ensure that acceptable experimental conditions were maintained. These conditions included a stable temperature $\left( \pm 2.0^{\circ} \mathrm{C}\right)$, minimum DO of $4.0 \mathrm{mg} / \mathrm{L}$, and $16 \mathrm{~h}$ of light per day. Salinity could vary $\pm 2.0 \mathrm{ppt}$, and the acceptable range for $\mathrm{pH}$ was \pm 0.5 units within each test container during the testing period. These limits and values are consistent with those outlined in the 1991 Implementation Manual. Water quality instruments were calibrated according to the manufacturers' specification or MSL protocols. 


\subsection{RESULTS}

\subsection{FIELD COLLECTIONS}

Sediment samples were collected on February 1, 1994, using a $0.1-\mathrm{m}^{2}$ van Veen grab, which sampled depths from $8 \mathrm{~cm}$ to $15 \mathrm{~cm}$. Two replicate 1 -gal samples from each station were received at MSL on February 3, 1994, and were immediately mixed in solvent-rinsed stainless-steel bowls and subsampled for chemical analysis. The remaining sediment was returned to its original sample jar and placed in a $4^{\circ} \mathrm{C}$ cold room until required for toxicity testing.

\subsection{SEDIMENT CHEMISTRY}

Sediment samples representing test treatments $\mathrm{IH}-2$ and $\mathrm{IH}-3$ and reference treatment IH-R2 were analyzed for a variety of contaminants. Included in these analyses were measurements of conventional sediment parameters, PAHs, dioxins, metals, and organotins. The purpose of these measurements was to provide a characterization of contaminants associated with the sediments.

\subsubsection{Conventional Measurements}

Conventional parameters measured in sediments were solids, grain size, and TOC, are summarized as percentages in Table 3.1. Raw data associated with these summaries and related QA measurements can be found in Appendix A, Tables A.1 through A.2. The $Q C$ evaluations presented in Appendix $A$ indicate that the relative standard deviations for most grain size fractions were within QC limits. In four grain size fractions these limits were exceeded; however, this represents $\leq 8 \%$ of the material in any one sediment. These analyses are acceptable for use in evaluating sediment-bound contaminants.

Table 3.1 shows that the percentages of solids were $76 \%$ and $50 \%$ for $\mathrm{IH}-2$ and IH-3 sediments, respectively. Reference sediment from station IH-R2 had $60 \%$ solids. In sediments from stations $\mathrm{IH}-2, \mathrm{IH}-3$, and $\mathrm{IH}-\mathrm{R} 2$ TOC values were $0.27 \%, 1.40 \%$, and $0.82 \%$, respectively. Sediment from station $\mathrm{IH}-2$ was composed of $93 \%$ sand. Sediments from stations $\mathrm{IH}-3$ and $\mathrm{IH}-\mathrm{R} 2$ were also dominated by sand $(74 \%$ and $81 \%$, respectively); 
TABLE 3.1. Summary of Percentage of Solids, Grain Size, and TOC in Sediment Samples

\begin{tabular}{|c|c|c|c|c|c|c|}
\hline \multirow{2}{*}{ Treatment } & \multicolumn{6}{|c|}{ Sediment Composition } \\
\hline & $\begin{array}{c}\text { Solids } \\
(\%)\end{array}$ & $\begin{array}{c}\text { Gravel } \\
\text { (\%) }\end{array}$ & $\begin{array}{c}\text { Sand } \\
(\%)\end{array}$ & $\begin{array}{l}\text { Silt } \\
(\%)\end{array}$ & $\begin{array}{l}\text { Clay } \\
\text { (\%) }\end{array}$ & $\begin{array}{l}\text { TOC } \\
(\%)\end{array}$ \\
\hline $\begin{array}{l}\text { IH-2 } \\
\text { IH-3 } \\
\text { IH-R2 }\end{array}$ & $\begin{array}{l}76.0 \\
50.0^{\text {(a) }} \\
60.0\end{array}$ & $\begin{array}{l}3.0 \\
0.0^{\text {(a) }} \\
0.0\end{array}$ & $\begin{array}{l}93.0 \\
74.0^{(a)} \\
81.0\end{array}$ & $\begin{array}{c}1.0 \\
11.5^{\text {(a) }} \\
7.0\end{array}$ & $\begin{array}{c}3.0 \\
14.5^{(a)} \\
12.0^{\text {a }}\end{array}$ & $\begin{array}{l}0.27 \\
1.40 \\
0.82\end{array}$ \\
\hline
\end{tabular}

however, approximately $25 \%$ of the material from these stations was composed of silts and clays. These data indicate that whereas the IH-R2 reference sediment grain size distribution was similar to both stations, it more closely resembled that of station IH-3.

\subsubsection{Polynuclear Aromatic Hydrocarbons}

Polynuclear aromatic hydrocarbon concentrations are summarized in Table 3.2. All data associated with these characterizations and related $Q A$ summaries are found in Appendix A, Tables A.3 through A.4 for sediments and Appendix B, Tables B.1 and B.2 for the rinsate blank. The $\mathrm{QC}$ evaluations for sediment and rinsate PAHs indicate that holding time limits were met, detection limit goals were met, and blanks were uncontaminated, . with the exception of low levels of benzo-a-anthracene in the aqueous blank and naphthalene in both matrix blanks. Surrogate recoveries were within acceptable limits, except for sediment recoveries of chrysene, benzo-b-fluoranthene, and dibenzo- $(a, h)$ anthracene. The MS/MSD analyses exhibited acceptable precision and accuracy; replicate analysis produced data within QA/QC limits; and analysis of SRMs was generally acceptable. The assessment of the PAH analyses suggests that these data are acceptable for use in evaluating sediment-bound contaminants.

Table 3.2 summarizes the measured concentrations of PAHs expressed as total low molecular-weight PAH (LPAH), total high-molecular-weight PAH (HPAH), and total PAH. Sediment from station IH-2 produced LPAH and HPAH levels of $3.56 \mu \mathrm{g} / \mathrm{kg}$ and $7.45 \mu \mathrm{g} / \mathrm{kg}$, respectively. PAH levels in IH-3 sediment were slightly higher, with $19.14 \mu \mathrm{g} / \mathrm{kg}$ and $54.47 \mu \mathrm{g} / \mathrm{kg}$ for LPAH and HPAH, respectively. Phenanthrene, 
TABLE 3.2. Summary of Total LPAH and HPAH, and Total PAH in Sediments and Rinsate Samples

\begin{tabular}{lrrr}
\hline & \multicolumn{3}{c}{ Concentration, $\mu \mathrm{g} / \mathrm{kg}$ dry } \\
\cline { 2 - 4 } Treatment & Total LPAH & Total HPAH & Total PAH \\
\hline Sediment Samples & & & \\
IH-2 & 3.56 & 5.45 & 11.01 \\
IH-3 & 19.14 & 38.44 & 73.61 \\
IH-R2 & 5.59 & & 44.04 \\
Aqueous Sample & & 22.2 & 161 \\
Rinsate Blank & & & \\
(a) Expressed as ng/L. & 139 & & \\
\hline
\end{tabular}

fluoranthene, and benzo(b)fluoranthene were dominant, with concentrations of approximately $10 \mu \mathrm{g} / \mathrm{kg}$. The reference sediment, IH-R2, produced levels of $5.59 \mu \mathrm{g} / \mathrm{kg}$ for LPAHs and $38.44 \mu \mathrm{g} / \mathrm{kg}$ for HPAHs. Comparison of the treatments $\mathrm{IH}-2$ and $\mathrm{IH}-3$ to the $\mathrm{IH}-$ $\mathrm{R} 2$ reference showed that the test treatment concentrations were similar to those of the reference sediment. The rinsate blank had only two detected PAHs, napthalene (139 ng/L) and benzola)anthracene $(22.2 \mathrm{ng} / \mathrm{L})$.

\subsubsection{Dioxins and Furans}

Dioxin and furan concentrations are summarized in Table 3.3. All data associated with these summaries and related $Q A$ measurements can be found in Appendix $A$, Tables A.5 through A. 6 for sediments and Appendix B; Tables B.3 through B.4 for the rinsate blank. The QC evaluations for dioxins presented in Appendix B show that holding time limits were met, blank contamination was not observed, detection limits goals were met, and surrogate recoveries were generally within acceptable ranges. The MS/MSD results showed acceptable precision. Analytical accuracy determination through the analysis of MS recoveries was within QA7QC limits for all congeners, except 123478-HxCDD, OCDD, and 23478-PeCDD in sediments and 123478-and 123678-HxCDF in the aqueous matrix. The overall assessment of the dioxin and furan analyses indicates that these data are acceptable for use in evaluating sediment-bound contaminants. 
TABLE 3.3. Summary of Dioxins and Furans in Sediment and Aqueous Samples

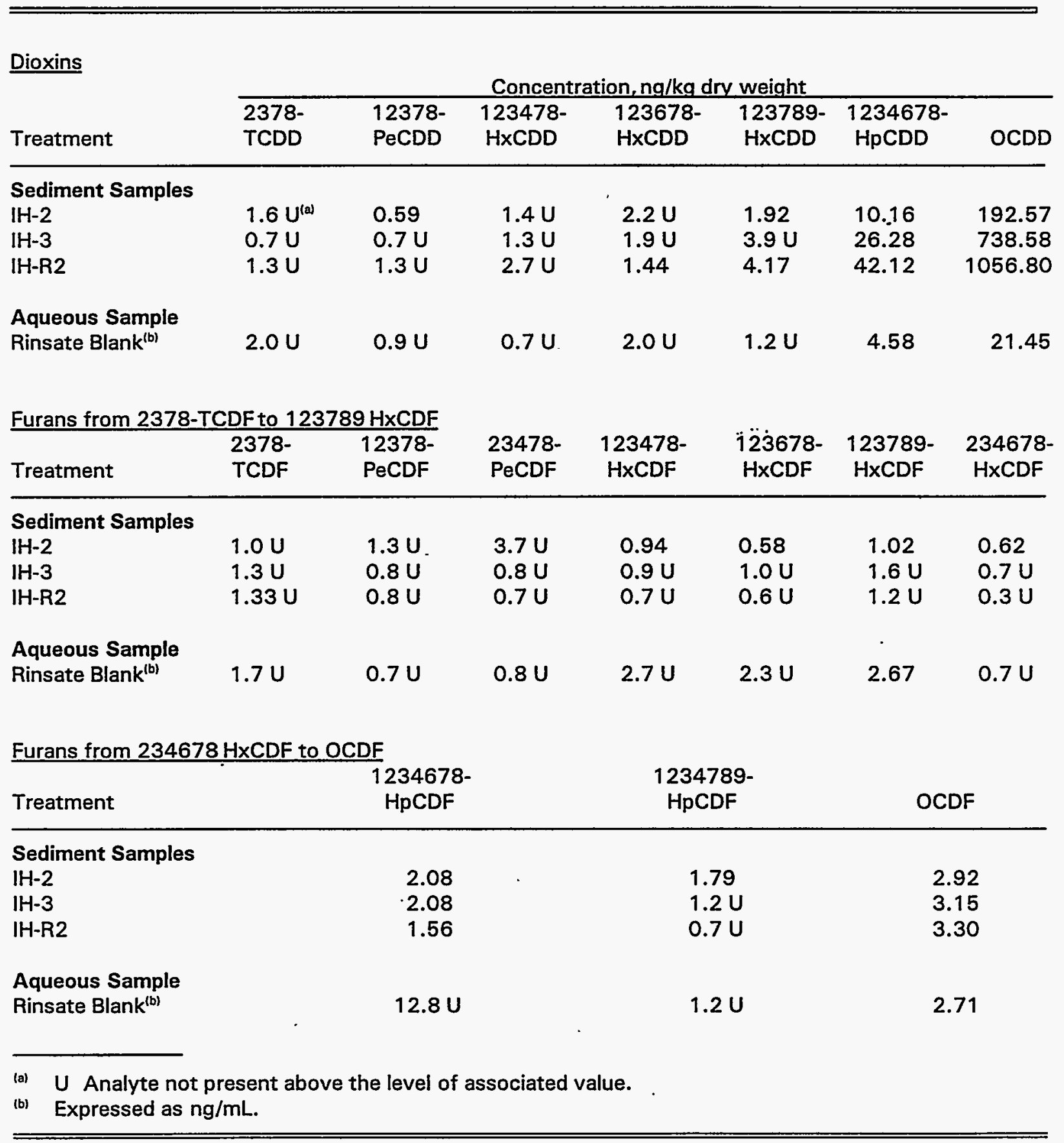


Table 3.3 summarizes the dioxin concentrations in the test and reference sediment treatments. The dioxin congener 2378-TCDD, considered the most toxic by EPA based on its toxicity equivalent factors (TEFs) (EPA 1988), was not detected in any of the samples analyzed. $12378-P e C D D$, considered one-half as toxic as $2378-T C D D$, was detected at $0.59 \mathrm{ng} / \mathrm{kg} \mathrm{dry}$ weight. Other less toxic congeners were detected in test and reference sediment treatments. The highest levels were associated with OCDD, which is considered ubiquitous (Tondeur 1987).

\subsubsection{Metals}

The concentration of metals in sediments and the rinsate blank is summarized in Tables 3.4 and 3.5. All data associated with these summaries and related $Q A$ measurements can be found in Appendix A, Table A.7 for sediments and Appendix B, Table B.5 for the rinsate blank. The QC evaluations for metals presented in Appendix B show that holding time limits were met and significant blank contamination was not present, although silver (Ag) was detected above the target detection limit. Detection limit goals were met, with the exception of that for mercury $(\mathrm{Hg})$. Since mercury levels were at or above the detection limit, this is not considered a problem. The MS analysis indicated acceptable precision for most metals, and replicate analyses yielded acceptable precision for most metals. Analytical accuracy was assessed by analysis of an SRM and was within QA/OC limits. The assessment of the metals analyses suggests that these data are acceptable for use in evaluating sediment-bound contaminants.

TABLE 3.4. Summary of Metals in Sediment and Rinsate Samples ( $\mathrm{Ag}$ to $\mathrm{Hg}$ )

\begin{tabular}{|c|c|c|c|c|c|c|}
\hline \multirow[b]{2}{*}{ Treatment } & \multicolumn{6}{|c|}{ Concentration, $\mathrm{mg} / \mathrm{kg}$ dry } \\
\hline & $\mathrm{Ag}$ & As & $\mathrm{Cd}$ & $\mathrm{Cr}$ & $\mathrm{Cu}$ & $\mathrm{Hg}$ \\
\hline \multicolumn{7}{|l|}{ Sediment Samples } \\
\hline $\mathrm{IH}-2$ & $0.01 U^{(\theta)}$ & 3.5 & $0.11 \mathrm{U}$ & $14.0 \mathrm{U}$ & 3.4 & $0.020 \mathrm{U}$ \\
\hline $\mathrm{IH}-3$ & 0.03 & 8.8 & 0.04 & 48.9 & 10.0 & 0.035 \\
\hline IH-R2 & $0.01 \mathrm{U}$ & 7.6 & 0.04 & 33.4 & 6.3 & 0.030 \\
\hline \multicolumn{7}{|l|}{ Aqueous Sample. } \\
\hline Rinsate Blank $k^{(b)}$ & 0.01 & 0.04 & 0.01 & 0.11 & 0.72 & 0.000 \\
\hline (a) U Analyte not & t above & evel o & ociated val & & & \\
\hline (b) Expressed as $\mu$ & & & & & & \\
\hline
\end{tabular}


TABLE 3.5. Summary of Metals in Sediment and Rinsate (Ni to $\mathrm{Zn}$ )

\begin{tabular}{|c|c|c|c|c|}
\hline \multirow[b]{2}{*}{ Treatment } & \multicolumn{3}{|c|}{ Concentration, $\mathrm{mg} / \mathrm{kg}$ dry } & \multirow[b]{2}{*}{$\mathrm{Zn}$} \\
\hline & $\overline{\mathrm{Ni}}$ & $\mathrm{Pb}$ & $\mathrm{Se}$ & \\
\hline \multicolumn{5}{|l|}{ Sediment Sample } \\
\hline $\mathrm{IH}-2$ & 4.9 & 5.3 & $0.128 U^{(a)}$ & 17.3 \\
\hline $\mathrm{IH}-3$ & 9.2 & 11.2 & 0.149 & 36.5 \\
\hline IH-R2 & 9.3 & 11.2 & 0.243 & 32.6 \\
\hline \multicolumn{5}{|l|}{ Aqueous Sample } \\
\hline Rinsate Blank ${ }^{(\mathbf{b})}$ & 0.5 & 0.1 & 0.39 & 0.21 \\
\hline
\end{tabular}

The data summarized in Tables 3.4 and 3.5 indicate that the $\mathrm{IH}-2$ sediment had metals concentrations that were consistently below those of the IH-R2 reference sediment. Levels of metals in station IH-3 sediments were generally similar to those of the reference sediment, with the exception of elevated levels of chromium, copper, and zinc. The rinsate blank had metals concentrations that were generally near or below detection limits.

\subsubsection{Organotins}

Organotin concentrations are summarized in Table 3.6. All data associated with these summaries and related QA measurements can be found in Appendix A, Table A.8 for sediments and Appendix B, Tables B.6 for the rinsate blank. Quality control evaluations for organotins, presented in Appendix B, show that holding time limits were met. Method blanks were uncontaminated, and detection limit goals were met in all sediment samples. The MS/MSD analyses indicated low percentage of recovery for mono- and dibutyltin; replication showed precision within acceptable limits for tributyltin.

No detectable concentrations of mono-, di-, or tributyltin were found in the sediment samples. A concentration of $29.1 \mathrm{ng} / \mathrm{mL}$ of dibutyltin was found in the rinsate blank, but does not appear to have affected the integrity of sediment samples. 
TABLE 3.6. Summary of Organotins in Sediment and Rinsate Samples

\begin{tabular}{|c|c|c|c|}
\hline \multirow[b]{2}{*}{ Treatment } & \multicolumn{3}{|c|}{ Concentration, $\mu \mathrm{g} / \mathrm{kg}$ dry } \\
\hline & Monobutyltin & Dibutyltin & Tributyltin \\
\hline $\begin{array}{l}\text { Sediment Sample } \\
\mathrm{IH}-2 \\
\mathrm{IH}-3 \\
\mathrm{IH}-\mathrm{R} 2\end{array}$ & $\begin{array}{l}0.25 U^{(a)} \\
0.25 U \\
0.25 U\end{array}$ & $\begin{array}{l}0.41 U \\
0.41 U \\
0.41 U\end{array}$ & $\begin{array}{l}0.43 U \\
0.43 U \\
0.43 U\end{array}$ \\
\hline $\begin{array}{l}\text { Aqueous Sample } \\
\text { Rinsate Blank }\end{array}$ & $0.25 \mathrm{U}$ & $29.1 U$ & $0.43 \mathrm{U}$ \\
\hline $\begin{array}{l}\text { (a) U Analyte not } \\
\text { (b) Expressed as n }\end{array}$ & above the le & value. & \\
\hline
\end{tabular}

\subsection{TOXICOLOGICAL TESTING}

The following section reports the results of the water-column testing. For each treatment, SPP preparations were mixed on the day of testing; however, separate preparations were used for each of the three species. On the first round of testing, ammonia levels were measured for the $100 \%$ SPP preparation for each treatment. Ammonia concentrations were $2.27 \mathrm{mg} / \mathrm{L} \mathrm{NH}_{3}$ for $\mathrm{IH}-2$ and $0.47 \mathrm{mg} / \mathrm{L} \mathrm{NH}_{3}$ for treatment $\mathrm{IH}-3$. These levels are below the no-observable-effects concentration (NOEC) for ammonia for all three species and indicate that toxicity due to ammonia was not a factor for these sediments.

\subsubsection{6-Hour Suspended-Particulate-Phase Static Test with M. beryllina}

The results of the 96-h SPP static test with $M$. beryllina are presented in Table 3.7. Supporting data related to the test are presented in Appendix C, Tables C.1 through C.4. All water quality parameters remained within acceptable ranges during the test. This test was validated by $>90 \%$ survival in the $0 \%$ SPP seawater controls. The results of the reference toxicant test produced an $\mathrm{LC}_{50}$ of $90.8 \mu \mathrm{g} / \mathrm{L}$ (copper) with a $95 \%$ confidence interval of $79.4 \mu \mathrm{g} / \mathrm{L}$ to $103.8 \mu \mathrm{g} / \mathrm{L}$. This is within the MSL limits of $70.8 \mu \mathrm{g} / \mathrm{L}$ to $136.0 \mu \mathrm{g} / \mathrm{L} \mathrm{CuSO}_{4}$ ( $n=13$ ), demonstrating appropriate test organism sensitivity.

No significant decrease in survival was observed in $\mathrm{IH}-2$ treatments when compared with the 0\% SPP control, and the $\mathrm{LC}_{50}$ was $>100 \%$ SPP. M. beryllina survival in IH-3 SPP was significantly reduced to $72 \%$ in the $100 \%$ SPP preparation. There was, however, no calculable $\mathrm{LC}_{50}$ since survival remained above $50 \%$. 
TABLE 3.7. Summary Results for 96-hour Suspended-Particulate-Phase Static Test with $M$. beryllina

\begin{tabular}{cccc}
\hline \hline Treatment & $\begin{array}{c}\text { SPP } \\
(\%)\end{array}$ & $\begin{array}{c}\text { Survival } \\
(\%)\end{array}$ & $\begin{array}{c}\text { Statistically } \\
\text { Significant Difference }\end{array}$ \\
\hline IH-2 & 0 & 90.0 & \\
IH-2 & 10 & 88.0 & No \\
IH-2 & 50 & 88.0 & \\
IH-2. & 100 & 92.0 & Yes \\
IH-3 & 0 & 92.0 & \\
IH-3 & 10 & 86.0 & 78.0 \\
IH-3 & 50 & 72.0 & \\
IH-3 & 100 & & \\
& & & \\
la) Denotes whether or not a statistically significant difference was detected between the $0 \%$ \\
SPP and 100\% SPP treatments (t-test, $a=0.05)$.
\end{tabular}

\subsubsection{6-Hour Suspended-Particulate-Phase Static Test with M. bahia}

The results of the 96-h SPP static test with $M$. bahia are presented in Table 3.8. Supporting data related to the test are presented in Appendix D, Tables D.1 through D.4. All water quality parameters remained within acceptable limits throughout the $96-h$ test. This test was validated by $>90 \%$ survival in the controls. The results of the reference toxicant test produced an $\mathrm{LC}_{50}$ of $277.8 \mu \mathrm{g} / \mathrm{L} \mathrm{CuSO}_{4}$, with a $95 \%$ confidence interval of $218.3 \mu \mathrm{g} / \mathrm{L}$ to $353.4 \mu \mathrm{g} / \mathrm{L} \mathrm{CuSO}_{4}$. This is slightly higher than that seen in other studies conducted at MSL with this species and suggests that the mysids used in this study could have been slightly less sensitive to toxicants than were populations used in previous tests. Test organism survival in all treatments and SPP concentrations exceeded $86 \%$. Since $50 \%$ mortality relative to control was not observed, the LC $_{50}$ for both treatments was $>100 \%$ SPP. There was no significant decrease in mysid survival in either of the SPP treatments. 
TABLE 3.8. Summary Results for 96-hour Suspended-Particulate-Phase Static Test with M. bahia

\begin{tabular}{|c|c|c|c|}
\hline Treatment & $\begin{array}{l}\text { SPP } \\
\text { (\%) }\end{array}$ & $\begin{array}{c}\text { Survival } \\
(\%)\end{array}$ & Significant Difference ${ }^{(a)}$ \\
\hline $\begin{array}{l}\mathrm{IH}-2 \\
\mathrm{IH}-2 \\
\mathrm{IH}-2 \\
\mathrm{IH}-2\end{array}$ & $\begin{array}{r}0 \\
10 \\
50 \\
100\end{array}$ & $\begin{array}{l}98.0 \\
84.0 \\
92.0 \\
86.0\end{array}$ & No \\
\hline $\begin{array}{l}\mathrm{IH}-3 \\
\mathrm{IH}-3 \\
\mathrm{IH}-3 \\
\mathrm{IH}-3\end{array}$ & $\begin{array}{r}0 \\
10 \\
50 \\
100\end{array}$ & $\begin{array}{l}90.0 \\
92.0 \\
94.0 \\
90.0\end{array}$ & No \\
\hline $\begin{array}{l}\text { (a) Denotes } \\
\text { SPP and }\end{array}$ & $\begin{array}{l}\text { tatistic } \\
\text { ents }(t\end{array}$ & lifference & ted between the $0 \%$ \\
\hline
\end{tabular}

\subsubsection{8-Hour Suspended-Particulate-Phase Static Test with L. pictus}

The results of the L. pictus test are presented in Table 3.9. Supporting data related to the test are presented in Appendix E, Tables E.1 through E.4. All water quality parameters remained within acceptable limits throughout the test. Examination of the data presented in Table 3.9 shows that mean survival in the $0 \%$ seawater controls was above $90 \%$ and mean normal larval development was greater than $87 \%$. This validates the test, since it exceeds both the minimum of $90 \%$ larval survival and $70 \%$ normal larvae relative to stocking density. The reference toxicant exposure produced an $\mathrm{EC}_{50}$ of $41.5 \mu \mathrm{g} / \mathrm{L}$ (copper) with a $95 \%$ confidence interval of $37.2 \mu \mathrm{g} / \mathrm{L}$ to $46.4 \mu \mathrm{g} / \mathrm{L}$, within the normal range of responses for $L$. pictus to copper. The $L C_{50}$ was $>100 \mu \mathrm{g} / \mathrm{L}$ copper, higher than normal control limits for this species, which indicates the gametes used in this test may be slightly less sensitive to contaminants than were those used in previous tests.

Mean survival in test exposures exceeded $77 \%$ in all SPP concentrations for both treatments. No significant differences were calculated between the $0 \%$ controls and $100 \%$ SPP treatments. Since a $50 \%$ decrease in survival was not observed relative to the seawater control, an LC $_{50}$ is not calculable; and there is no evidence to indicate acute-lethal toxicity of SPP produced from test sediments to the larval form of this species. 
Mean normal larval development in SPP produced from $\mathrm{IH}-2$ sediments produced no significant acute-sublethal response. Normal development was significantly reduced only in SPP made from $\mathrm{IH}-3$ sediments, with $1.0 \%$ normal development in the $100 \%$ preparation. The $\mathrm{EC}_{50}$ for this treatment was $66.9 \%$ SPP with $95 \%$ confidence intervals of $59.9 \%$ to $74.9 \%$ SPP. Larval abnormalities were dominated by developmentally delayed larvae (in gastrula stage) and exogastrula.

TABLE 3.9. Summary Results for 48-hour Suspended-Particulate-Phase Static Test with L. pictus

\begin{tabular}{|c|c|c|c|c|c|}
\hline Treatment & $\begin{array}{l}\text { SPP } \\
(\%)\end{array}$ & $\begin{array}{c}\text { Mean Survival } \\
(\%)\end{array}$ & $\begin{array}{l}\text { Significant } \\
\text { Difference }^{\text {(a) }}\end{array}$ & $\begin{array}{c}\text { Mean Normal } \\
(\%)\end{array}$ & $\begin{array}{r}\text { Significant } \\
\text { Difference }\end{array}$ \\
\hline $\begin{array}{l}\mathrm{IH}-2 \\
\mathrm{IH}-2 \\
\mathrm{IH}-2 \\
\mathrm{IH}-2\end{array}$ & $\begin{array}{r}0 \\
10 \\
50 \\
100\end{array}$ & $\begin{array}{l}95.1 \\
86.3 \\
87.5 \\
92.6\end{array}$ & No & $\begin{array}{r}90.9 \\
81.1 \\
79.9 \\
1.0\end{array}$ & Yes \\
\hline $\begin{array}{l}\mathrm{IH}-3 \\
\mathrm{IH}-3 \\
\mathrm{IH}-3 \\
\mathrm{IH}-3\end{array}$ & $\begin{array}{r}0 \\
10 \\
50 \\
100\end{array}$ & $\begin{array}{l}90.6 \\
83.2 \\
77.3 \\
93.1\end{array}$ & No & $\begin{array}{l}87.6 \\
81.3 \\
75.2 \\
89.9\end{array}$ & No \\
\hline $\begin{array}{l}\text { (a) Denotes } \\
\text { SPP and }\end{array}$ & $\begin{array}{r}\text { er or } \\
\text { SPP }\end{array}$ & $\begin{array}{l}\text { tistically signifi } \\
\text { its (t-test, } a=\end{array}$ & $\begin{array}{l}\text { nt difference } \\
05 .\end{array}$ & s detected bet & $n$ the $0 \%$ \\
\hline
\end{tabular}




\subsection{DISCUSSION AND CONCLUSIONS}

The following section presents a discussion of data pertinent to the Charleston Intensive Project, including an evaluation of sediment contamination and toxicological testing. Sediment chemistry results are discussed here in support of toxicological testing results.

\subsection{SAMPLE CHEMISTRY}

Sediments from both $\mathrm{IH}-2$ and $\mathrm{IH}-3$ were predominantly sand, with relatively little associated TOC. Station $\mathrm{IH}-3$ had higher levels of silts and clays $(26 \%)$ and TOC (1.40\%) than did $\mathrm{IH}-2$ ( $4 \%$ and $0.27 \%$, respectively). $\mathrm{PAH}$ concentrations in $\mathrm{IH}-2$ sediment were below reference lëvels for both LPAHs and HPAHs. In station IH-3 sediment, PAH concentrations were 1.8 times those of reference sediments. The sediment samples had detectable levels of PAHs. Only dioxin/furan congeners that are considered ubiquitous and nontoxic were detected at levels above $1 \mathrm{ng} / \mathrm{kg}$ dry weight in the tested sediment samples, with the exception of sample IH-3 (EPA 1988; Tondeur 1987). Metals were present at below reference levels in station $\mathrm{HH}-2$ sediment. Chromium ( $48.9 \mathrm{mg} / \mathrm{kg})$, copper (10.0 $\mathrm{mg} / \mathrm{kg}$ ) and zinc $(36.5 \mathrm{mg} / \mathrm{kg}$ ) were slightly elevated in $\mathrm{IH}-3$ sediment, in comparison with the reference sediment. None of the samples analyzed in this study had detectable levels of organotins. Levels of all contaminants tested in the rinsate blank were relatively low, indicating no appreciable contamination of sediments by field sampling techniques.

When compared with sediments collected from stations $\mathrm{IH}-2$ and $\mathrm{IH}-3$ in 1992, the 1994 sediments had substantially reduced contaminant levels. In the 1992 study, both $\mathrm{IH}$ 2 and $\mathrm{IH}-3$ sediments were greater than $90 \%$ silts and clays, with TOC levels of over $4 \%$, as opposed to predominantly sand in this study. PAH levels measured in the 1992 study for these stations were $4(\mathrm{IH}-3)$ and 18 times $(\mathrm{IH}-2)$ those in 1994, whereas the PAH concentrations in IH-R2 reference were nearly unchanged. Inner Harbor sediments were not tested for metals in 1992. In 1992, tributyltin was detected in both $\mathrm{IH}-2$ and $\mathrm{IH}-3$ sediments. 
The loss of the fine-grained material found in 1992 could partially account for some of the reduced contaminant levels in sediments. This could be a result of seasonal riverine sediment flux or a long-term alteration of the sediment grain size distribution.

\subsection{TOXICOLOGICAL TESTING}

Acute water-column toxicity is defined by the 1991 Implementation Manual as the concentration of SPP that is lethal to $50 \%$ of the test population. This concentration is expressed as an $\mathrm{LC}_{50}$. If a treatment generates less than $50 \%$ mortality, an $\mathrm{LC}_{50}$ is not calculable, and the value of $>100 \%$ is reported.

Water-column toxicity was evaluated by exposing three species of test organisms to three concentrations of SPP: $10 \%, 50 \%$, and $100 \%$. A filtered-seawater control (0\% SPP) was included with each test. The SPP test organisms were M. beryllina, M. bahia, and the larvae of $L$. pictus. None of the water-column tests produced an acute-lethal toxicity of greater than $50 \%$. Therefore, all of the SPP treatments tested generated an $L_{50}$ of $>100 \%$ SPP.

The $100 \%$ preparation of $\mathrm{IH}-3$ SPP did show significantly reduced survival in the M. beryllina test and significantly reduced normal L. pictus development $\left(\mathrm{EC}_{50}=66.9 \%\right)$, indicating that some response from water-column organisms is present in $\mathrm{IH}-3 \mathrm{SPP}$ preparations.

\subsection{CONCLUSIONS}

The tiered approach to evaluating potential impacts of ocean disposal of dredged materials is presented in the 1991 Implementation Manual. This approach consists of a series of activities (tests) and decision modules (determination of compliance) that aid in interpreting physical, chemical, and biological data related to the evaluation of proposed dredged sediment. Under Tier III and IV evaluations, both benthic and water-column bioassays are required. This study evaluated water-column toxicity. The bioaccumulation potential of the Inner Harbor sediment was evaluated in the 1992 study (Ward et al. 1993). The following summarizes the tests conducted using the determination of compliance definitions provided by the 1991 Implementation Manual. 
The toxicity from exposure of the water column to dredged material was estimated by exposing three sensitive marine species (M. beryllina, M. bahia, L. pictus) to three concentrations of SPP prepared from Entrance Channel treatments and a seawater-only control. The SPP tests showed no acute toxicity in all three bioassays. Under the 1991 Implementation Manual guidelines, the limiting permissible concentration (LPC) for dissolved plus suspended contaminants (represented by SPP) cannot exceed $0.01 \%$ of the acutely toxic concentration $\left(L C_{50}\right)$ outside the boundary of the disposal site during the 4-h initial-mixing period or anywhere in the marine environment after the 4-h-initial mixing period. The SPP tests indicate that dredged materials from stations $\mathrm{IH}-2$ and $\mathrm{IH}-3$ would be suitable for open-ocean disposal according to the 1991 Implementation Manual guidelines.

Tissue chemistry from bioaccumulation testing performed in 1992 (Ward et al. 1993) indicated no potential for bioaccumulation in Inner Harbor test treatments. Tier IV evaluation indicates that Inner Harbor treatments meet both water-column criteria and should not contribute to tissue-bound contaminants. 



\subsection{REFERENCES}

APHA (American Public Health Association). 1989. Method 5310 Standard Methods for the Examination of Water and Wastewater, 17th ed., APHA, AWWA, WPCF, Washington, D.C.

EPA (U.S. Environmental Protection Agency). 1986. Test Methods for Evaluating Solid Waste: Physical/Chemical Methods. EPA-955-001-00000. U.S. Environmental Protection Agency, Government Printing Office, Washington D.C.

EPA (U.S. Environmental Protection Agency). 1988. Integrated Risk Information System (IRIS), Vols. 1 and 2. EPA 600/8-88/032A, B. U.S. Environmental Protection Agency, Office of Health and Environmental Assessment, Washington, D.C.

EPA (U.S. Environmental Protection Agency). 1990a. Method 8290 Analytical Procedures and Quality Assurance for Multimedia Analysis of Polychlorinated Dibenzo-p-Dioxins and Polychlorinated Dibenzofurans by High Resolution Gas Chromatography/High Resolution Mass Spectrometry. U.S. Environmental Protection Agency, Washington, D.C.

EPA (U.S. Environmental Protection Agency). 1990b. Method 200.8 Determination of Metals and Trace Elements by Inductively Coupled Plasma/Mass Spectrometry. U.S. Environmental Protection Agency, Washington, D.C.

EPAJUSACE (U.S. Environmental Protection Agency/U.S. Army Corps of Engineers). 1991. Evaluation of Dredged Material Proposed for Ocean Disposal Testing Manual. EPA-68-C8-0105. U.S. Environmental Protection Agency, Office of Marine and Estuarine Protection, Washington, D.C.

Finney, D. J. 1971. Probit Analysis. 3rd ed. Cambridge University Press, Cambridge.

Plumb, R. H., Jr. 1981. Procedure for Handling and Chemical Analyses of Sediment and Water Samples. Technical Report EPA/CE-81-1 Prepared for Great Lakes Laboratory, State University College at Buffalo, New York, for the U.S. Environmental Protection Agency/U.S. Army Corps of Engineers Technical Committee on Criteria for Dredged and Fill Material. Published by the U.S. Army Engineer Waterways Experiment Station, Vicksburg, Mississippi.

PSEP (Puget Sound Estuary Program). 1986. Recommended Protocols for Measuring Selected Environmental Variables in Puget Sound, Vols. 1 and 2. Prepared for the Puget Sound Estuary Program by Tetra-Tech, Inc., Bellevue, Washington.

Tondeur, Y. 1987. Method 8290 Analytical Procedures and Quality Assurance for Mültimedia Analysis of Polychlorinated Dibenzo-p-Dioxins and Polychlorinated Dibenzofurans by HighResolution Gas Chromotography/High Resolution Mass Spectrometry. Environmental Monitoring Systems Laboratory, Las Vegas, Nevada.

Unger, M. A., W. G. Macintyre, J. Greaves, and R. J. Huggett. 1986. "GC Determination of Butyltins in Natural Waters by Flame Photometric Detection of Hexyl Derivatives with Mass Spectrometric Confirmation." Chemosphere 15(4):461-470. 
Ward, J. A., W. W. Gardiner, M. R. Pinza, J. Q. Word. 1993. Ecological Evaluation of Proposed Dredged Material from Winyah Bay, South Carolina. PNL-8893. Prepared for the U.S. Army Corps of Engineers, Charleston, South Carolina. 


\section{APPENDIX A}

SEDIMENT CHEMISTRY DATA AND QUALITY CONTROL DATA 


\section{QA/QC SUMMARY}

Project:

Parameter:

Laboratory:

Matrix:

Holding Times

Blanks

Detection Limits

\section{Surrogate}

Internal Standards

Matrix Spike/Matrix

Spike Duplicate

Replication
Winyah Bay

Grain Size

Soil Technology, Inc

Sediment

All samples were analyzed within the specified 6 month holding period.

Not applicable in these analyses.

The detection limit of $1.0 \%$ was met for all samples.

Not applicable in these analyses.

Not applicable in these analyses.

One duplicate analysis was run. Totals of Gravel, sand, silt, and clay fractions produced RPDs ranging from $0 \%$ to $4 \%$, well below the $\leq 20 \%$ limit specified in the QA plan. However, if the samples are looked at as their individual sieve sizes, Sediment Sample IHR3 had 3 grain sizes out of the $\leq 20 \%$ range.

Not applicable for this analyses. 


\section{QA/QC SUMMARY}

\section{Project: \\ Parameter: \\ Laboratory: \\ Matrix:}

Holding Times

Blanks

Detection Limits

Surrogate

Internal Standards

Matrix Spike/Matrix
Spike Duplicate

SRMis
Winyah Bay

Polynuclear Aromatic Hydrocarbons (PAHs)

Battelle Ocean Sciences (BOS)

Sediment

Sediment samples were collected from February 1, 1994. Samples arrived at BOS on February 4, 1994, were extracted on February 8,1994 , and analyzed on February 11, 1994. The 30 day holding time prior to extraction was not exceeded; the 40-day holding time between extraction and analysis was not exceeded.

The criteria of 1 blank was met. HPAHs and LPAHs were not detected above the target detection limit of $30 \mu \mathrm{g} / \mathrm{kg}$, though the compound naphthalene and benzo-a-anthracene were detected in the procedural blank at a concentration above the MDL.

The detection limit goal of $30 \mu \mathrm{g} / \mathrm{kg}$ was met for all HPAH and LPAH compounds.

The criteria of a surrogate standard per sample was met. Four surrogate standards were evaluated: d8 naphthalene, d10 acenapthalene, 12 benzo(a)pyrene and d12 Dibenzo-a,h,janthracene. Surrogate recoveries were within the QA goals of $40 \%$ to $120 \%$.

The criteria of one matrix spike sample was met. The $40 \%$ to $120 \%$ criteria for spike recovery was met for the LPAH and HPAHs.

QA limits specify that the observed value for an SRM must be within $30 \%$ of the certified value. SRM data were not available for LPAHs. HPAH SRM data showed all compounds except chrysene, benzo(b)fluoranthene, and dibenzo(a,h)anthracene were within range. 
Project:

Parameter:

Laboratory:

Matrix:

Holding Times

Blanks

Detection Limits

\section{Surrogate}

Internal Standards
Winyah Bay/Georgetown Harbor

Dioxins and furans

Battelle/Columbus Operations

Sediment

Sediment samples were collected from February 1, 1994.

Sediment samples were received by BCO on February 4, 1994, extracted on February 22, 1994, and run on the GC/MS between March 22 and April 4, 1994. The 30 day holding time prior to extraction was not exceeded; the 40 day holding time between extraction and analysis was not exceeded.

One method blank was run, meeting requirements stated in the study QA plan. All dioxin and furan analytes were observed below the method detection limit (MDL) of $1.0 \mathrm{ng} / \mathrm{kg}$, which was elevated to almost twice the MDL. Trace levels of some dioxin analytes were noted in the method blank, although well below acceptable detection measures. Blank surrogate recoveries were within acceptable ranges.

Study detection limits were exceeded for several compounds in each of the sedimentss.

All samples were spiked with labeled surrogate internal standards (SIS) in order to assess the precision of the dioxin laboratory method. Acceptable surrogate percent recoveries $(40-120 \%)$ for internal standards were met for most compounds except 23478PeCDF-13c12 (9\%) in sediment IH-2, OCDD-13c12 (37\%) in sediment $\mathrm{IH}-3$, and $123478-\mathrm{H} \times \mathrm{CDD}-13 \mathrm{c} 12(22 \%)$ in sediment $\mathrm{IH}$ R2. 


\section{QA/QC SUMMARY}

Project:

Parameter:

Laboratory:

Matrix:

Holding Times

Blanks

Detection Limits

\section{Surrogate}

Internal Standards

SRMs
Winyah Bay/Georgetown Harbor

Metals

ICP/MS, GFAA: Battelle/Marine Sciences Laboratory, Sequim Sediment

The 6 month holding time for all metals was met.

One method blanks. was run for those metals analyzed by ICP/MS. The procedural blank was below method detection limits (MDL) for all metals except silver. Blanks showed levels of silver at $>1$ $\mathrm{mg} / \mathrm{kg}$, while detection limits are listed in the QA plan at 0.1 $\mathrm{mg} / \mathrm{kg}$. The blank run during the mercury analysis (CVAA) had no contamination.

Method detection limits were met for all the ICP/MS metals found in South Carolina sediment: $\mathrm{Ni}, \mathrm{Cu}, \mathrm{Cd}, \mathrm{Pb}, \mathrm{Ag}(0.1 \mathrm{mg} / \mathrm{kg})$, and Zn $(0.3 \mathrm{mg} / \mathrm{kg})$, except $\mathrm{Ag}(0.1 \mathrm{mg} / \mathrm{kg})$ which was $0.2 \mathrm{mg} / \mathrm{kg}$.

Surrogate internal standards are not required for the analysis of metals.

One standard reference material (SRM) was analyzed; two different SRM substances were focused on for all the metals methods. BEST-1 is certified for mercury and was measured within 30 percent from the certified values. SRM 1646 was also used to assess method precision for all other metals. All metals certified for SRM 1646 were within the acceptable limits outlined in the QA plan. 


\section{QA/QC SUMMARY}

\begin{abstract}
Project:
Parameter:

Laboratory:

Matrix:
\end{abstract}

Holding Times

Blanks

Detection Limits

Surrogate

Internal Standards

Matrix Spilse/Matrix Spike Duplicate

SRMs

\author{
Winyah Bay \\ Organotins \\ Battelle/Marine Sciences Laboratory \\ Sediment
}

Sediment samples were colleçted from February 1, 1994.

- Samples were extracted on February 8, 1994, and run on February 11,1994 . The 30 day holding time prior to extraction was exceeded; the 40 day holding time between extraction and analysis was not exceeded.

One method blank was run with all compounds below the method detection limit.

The detection limit goal of $10 \mu \mathrm{g} / \mathrm{kg}$ was met in the method blanks and the test sediment samples.

The criteria for a surrogate standard for each sample and blank was met. In all but three samples, the recoveries of tripentyltin were within the QC limits of $40 \%$ to $120 \%$ recovery.

The criteria of one matrix spike/matrix spike duplicate was met. The criteria of $40 \%$ to $120 \%$ recovery on spikes was met except for monobutyltin. Tetrabutyltin recovery was over $100 \%$; monobutyltin recovery was generally low $159 \%$ and $64 \%)$. The RPD between MS and MSD data was $\leq 30 \%$ for all compounds.

Certified PACS was analyzed. Recovery was within QC criteria, except for monobutyltin (37\%). 
TABLE A.1. Summary of Sediment Grain Size, Charleston Intensive Project

\begin{tabular}{|c|c|c|c|c|c|c|}
\hline \multirow[b]{2}{*}{ Treatment } & \multicolumn{6}{|c|}{ Total Percent } \\
\hline & $\begin{array}{c}\text { Gravel } \\
\geq 2000 \mu \mathrm{m}\end{array}$ & $\begin{array}{l}\text { Sand } \\
62.5- \\
2000 \mu \mathrm{m} \\
\end{array}$ & $\begin{array}{c}\text { Silt } \\
3.9- \\
62.5 \mu \mathrm{m} \\
\end{array}$ & $\begin{array}{c}\text { Clay } \\
\leq 3.9 \mu \mathrm{m}\end{array}$ & TOC & Solids \\
\hline \multicolumn{7}{|l|}{ Sediment Results } \\
\hline $\mathrm{IH}-2$ & 3 & 93 & 1 & 3 & 0.27 & 76 \\
\hline $\mathrm{HH}-3$ & 0 & 74 & 11 & 15 & 1.40 & 50 \\
\hline IH-3 Duplicate & 0 & 74 & 12 & 14 & $N A^{(a)}$ & 50 \\
\hline IH-R2 & 0 & 81 & 7 & 12 & 0.82 & 60 \\
\hline \multicolumn{7}{|c|}{ Quality Control Data } \\
\hline IH-3 Replicate 1 & 0 & 74 & 11 & 15 & 1.40 & 50 \\
\hline IH-3 Replicate 2 & 0 & 74 & 12 & 14 & NA & 50 \\
\hline RSD & $0 \%$ & $0 \%$ & $0 \%$ & $1 \%$ & NA & $0 \%$ \\
\hline
\end{tabular}

(a) NA Not applicable. 
TABLEA.2. Summary of Sediment Grain Size, Charleston Intensive Project

\begin{tabular}{|c|c|c|c|c|c|c|c|c|c|c|c|c|c|c|c|c|}
\hline \multirow{2}{*}{\multicolumn{2}{|c|}{$\begin{array}{c}\text { phi } \\
\mu \mathrm{m}\end{array}$}} & \multicolumn{15}{|c|}{ Percent at Size Fraction } \\
\hline & & $\underline{4750}$ & $\begin{array}{l}4750- \\
2000 \\
\end{array}$ & $\begin{array}{r}2000- \\
850 \\
\end{array}$ & $\begin{array}{r}850 \\
425- \\
\end{array}$ & $\begin{array}{l}425- \\
250 \\
\end{array}$ & $\begin{array}{l}250- \\
106 \\
\end{array}$ & $\begin{array}{c}106- \\
75\end{array}$ & $\begin{array}{r}75- \\
62.5 \\
\end{array}$ & $\begin{array}{c}4 \\
62.5- \\
31.2 \\
\end{array}$ & $\begin{array}{c}5 \\
31.2- \\
15.6 \\
\end{array}$ & $\begin{array}{c}6 \\
15.6- \\
7.8\end{array}$ & $\begin{array}{c}7 \\
7.8- \\
3.9\end{array}$ & $\begin{array}{r}8 \\
3.9- \\
1.9\end{array}$ & $\begin{array}{r}9 \\
1.9- \\
0.9\end{array}$ & $\begin{array}{r}10 \\
\leq 0.9\end{array}$ \\
\hline
\end{tabular}

Sediment Results

$\mathrm{IH}-2$

IH-3

IH-3 Duplicate

IH-R2

$\begin{array}{lllll}2 & 7 & 13 & 16 & 55 \\ 0 & 2 & 16 & 20 & 34 \\ 0 & 4 & 16 & 19 & 34 \\ 0 & 1 & 4 & 8 & 58\end{array}$

Quality Control Data

IH-3 Replicate 1

IH-3 Replicate 2

$\begin{array}{cccc}0 & 0 & 2 & 16 \\ 0 & 0 & 4 & 16 \\ 0 \% & 0 \% & 424 \% \text { (a) } & 0 \%\end{array}$

$\begin{array}{ll}20 & 34 \\ 19 & 34 \\ 4 \% & 0 \%\end{array}$

$\begin{array}{lll}\mathbf{5 5} & 1 & 1 \\ 34 & 1 & 1 \\ 34 & 1 & 0 \\ 58 & 9 & 1\end{array}$

$\begin{array}{lllllll}0 & 0 & 0 & 1 & 0 & 1 & 2 \\ 0 & 2 & 4 & 5 & 4 & 3 & 8 \\ 1 & 2 & 3 & 6 & 4 & 2 & 8 \\ 1 & 1 & 2 & 3 & 3 & 2 & 7\end{array}$

(a) Value exceeds relative standard deviation range of $\leq 20 \%$. 
TABLE A.3. Sediment Results and Quality Control Data for Low Molecular Weight Polynuclear Aromatic Hydrocarbons (LPAHs), Charleston Intensive Project

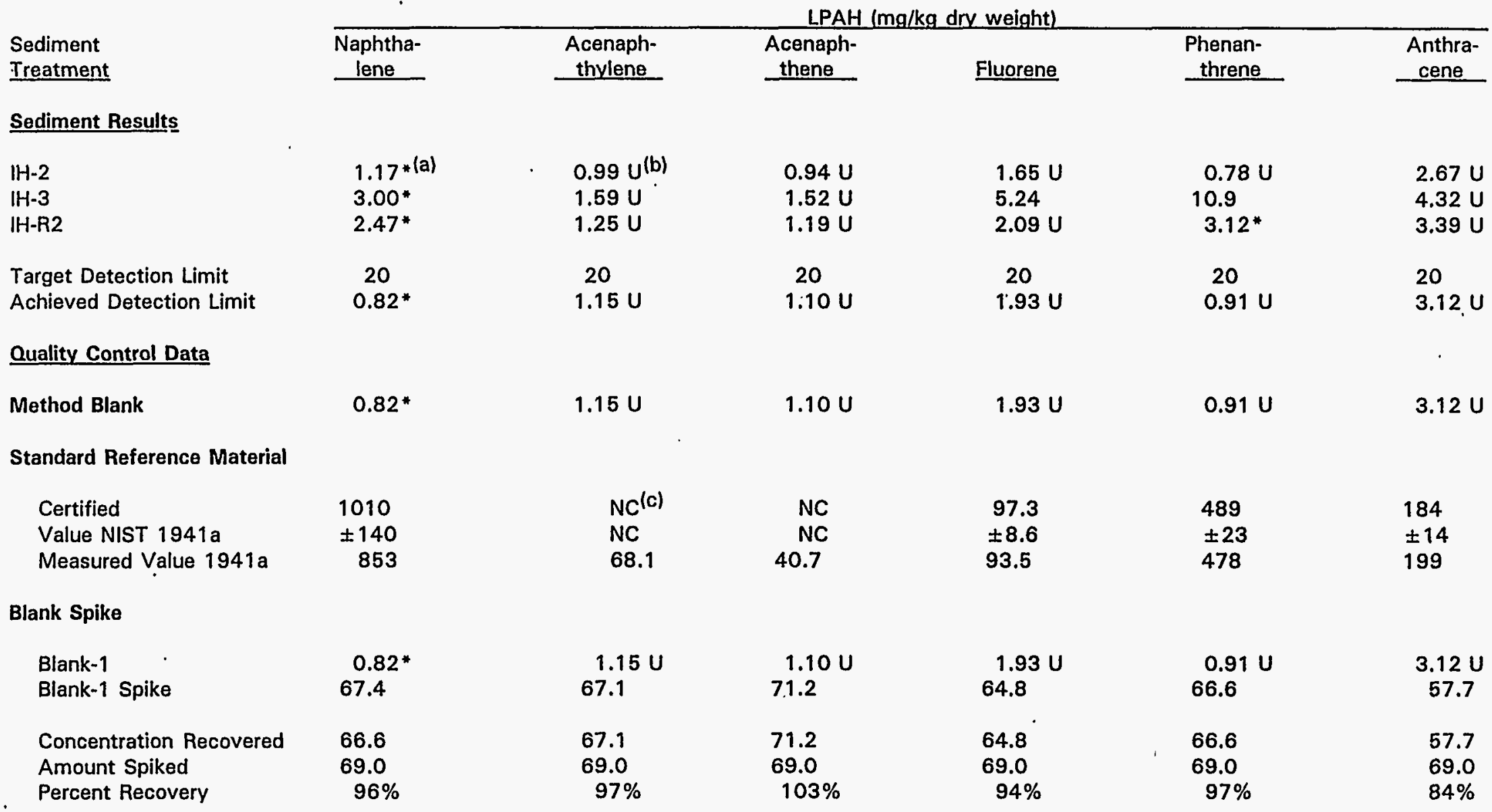

(a) - Ion ratio out or confirmation ion not detected.

(b) $U$ Not detected at or above detection limit shown.

(c) NC Not Certified. 
TABLE A.4. Sediment Results and Quality Control Data for High Molecular Weight Polynuclear Aromatic Hydrocarbons (HPAHs); Charleston Intensive Project

HPAH $(\mu \mathrm{g} / \mathrm{kg}$ dry weight)

\section{Treatment}

Sediment Results

\section{$1 \mathrm{H}-2$}

$\mathrm{IH}-3$

IH-R2

Target Detection Limit

Achieved Detection Limit

\section{Quality Control Data}

$\frac{7}{6}$
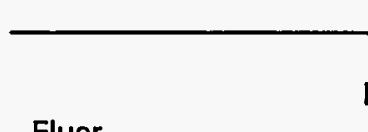

anthene

Benzo(a)-
anthra-

Pyrene

$\begin{array}{lll}2.39^{*(a)} & 1.42 U^{(b)} & 2.55^{*} \\ 8.39 & 4.91 & 6.38 \\ 7.67 & 4.80 & 5.05 \\ 20 & 20 & 20\end{array}$

$\begin{array}{ll}0.78 \mathrm{U} & 2.51^{*} \\ 4.98 & 9.79 \\ 2.86 & 7.58\end{array}$

$0.99 U$

4.82*

3.78 *

20.

2.30

1.65

3.08

0.91

20

0.39

20

1.15

Benzo(k)-

fluor-
anthene

Benzo(a)
pyrene

Indeno-

Dibenzo-

anthra-

pyrene

cene

Benzo-

pyrene pyrene

$\begin{array}{lll}0.95 U & 3.26 U & 3.51 U \\ 3.54 & 5.65 & 5.67 U\end{array}$

$4.12 \cup \quad 4.44 U$

$2.90 \mathrm{U}$

2.60*

20

$1.11 \quad 3.80$

20

\section{0}

2.304

$1.65 \mathrm{U} \quad 3.08$ *

$0.91 U$

$0.39 \mathrm{U}$

$1.15 \mathrm{U}$

$1.11 \mathrm{U}$

$3.80 U \quad 4.90 U$

3.39

Standard Reference Material

\section{Certified}

Value NIST 1941a

\section{1}

Measured Value 1941a

\pm 78
811

811

427

$\pm 25$

647

380

$\pm 24$

740
\pm 110

361

Blank Spike

$\begin{array}{lccc}\text { Blank-1 } & 2.30 \mathrm{U} & 1.65 \mathrm{U} & 3.08^{*} \\ \text { Blank-1 Spike } & 61.7 & 57.2 & 56.0 \\ & & & \\ \text { Concentration Recovered } & 61.7 & 57.2 & 52.9 \\ \text { Amount Spiked } & 69.0 & 69.0 & 69.0 \\ \text { Percent Recovery } & 89 \% & 83 \% & 77 \%\end{array}$

$0.91 \mathrm{U}$

58.0

$0.39 \mathrm{U}$
71.4

$1.15 \mathrm{U}$
70.9

$1.11 \mathrm{U}$
62.9

61.0

501

563

520

$\pm 9.7$

129@

525

58.0

69.0

71.4

69.0

70.9

$84 \%$

$103 \%$

62.9

69.0

$91 \%$.

$\begin{array}{ll}61.0 & 64.9 \\ 69.0 & 69.0 \\ 88 \% & 94 \%\end{array}$

(a) * Ion ratio out or confirmation ion not detected.

(b) U Not detected at or above detection limit shown.

(c)@Outside QC criteria range $( \pm 30 \%)$. 
TABLE A.5. Sediment Results and Quality Control Data for Dioxins, Charleston Intensive Project

Sediment

Treatment

\begin{tabular}{|c|c|c|}
\hline $\begin{array}{l}2378- \\
\text { TCDD }\end{array}$ & $\begin{array}{l}12378 \\
\text { PeCDD } \\
\end{array}$ & $\begin{array}{l}123478- \\
\mathrm{H} \times \mathrm{CDD}\end{array}$ \\
\hline $1.6^{*(a)}$ & 0.59 & $1.4 U^{(b)}$ \\
\hline $0.7 \mathrm{U}$ & $0.7 \mathrm{U}$ & $1.3 \mathrm{U}$ \\
\hline $1.3 \mathrm{U}$ & $1.3 \mathrm{U}$ & $2.7^{*} U$ \\
\hline
\end{tabular}

Dioxins (ng/kg dry weight)

Sediment Results

$\mathrm{IH}-2$

$\mathrm{IH}-3$

IH-R2

20

Target Detection Limit

Achieved Low DL

0.7

Achieved High DL.

$$
2.0
$$

20

0.0

1.3

20

0.7
2.7

123678-

$123789-$

1234678 .

$\mathrm{H} \times \mathrm{CDD}$

HXCDD

$\mathrm{HpCDD}$

$\underline{O C D D}$

Quality Control Data

Method Blank

$0.2 U$

$0.2 U$

$0.2 U$

$2.2 \mathrm{U}$
$1.9 \mathrm{U}$

1.44

1.92

$3.9 \mathrm{U}$

4.17

10.16

26.28

192.57

20

0.0

20

1.9

0.0

42.12

738.58

20

0.0
0.0

20

3.9

0.0

0.0

Blank Spike

Matrix Spike 200

Concentration Revovered 125

125
$63 \%$

Percent Recovery

$63 \%$

131

$66 \%$

$0.3 \mathrm{U}$

$$
0.3 U
$$

0.37

1.58

Matrix Spike

$\begin{array}{lrrr}\text { IH-2 Matrix Spike } & 251 & 251 & 251 \\ \text { Concentration Recovered } & 173 & 231 & 183 \\ \text { Percent Recovery } & 69 \% & 92 \% & 73 \% \\ & & & \\ \text { IH-3 Matrix Spike } & 280 & 280 & 280 \\ \text { Concentration Revovered } & 151 & 152 & 159 \\ \text { Percent Recovery } & 54 \% & 54 \% & 57 \% \\ & & & \\ \text { IH-R2 Matrix Spike } & 272 & 272 & 272 \\ \text { Concentration Revovered } & 174 & 179 & 59 \\ \text { Percent Recovery } & 64 \% & 66 \% & 22 \% @\end{array}$

200

134

200

116

$58 \%$

200
167
$42 \%$

$N A^{(c)}$

NA

NA

251
176
$70 \%$
280
160
$57 \%$
272
168
$62 \%$

251

173

$69 \%$

251
332

332
$66 \%$

NA

176

280

160

280

138

$49 \%$

280

207 $37 \%$ (d)

272

153

$56 \%$

272

242

$44 \%$

NA
NA

NA

(a) * Ion ratio out or confirmation ion not detected.

(b) U Not detected at or above detection limit shown.

(c) @ Outside OC criteria range (40-135\%). 
TABLE A.6. Sediment Results and Quality Control Data for Furans, Charleston Intensive Project

Furans (ng/kg dry weight)

Sediment

Treatment

Sediment Results

IH-2

IH-3

IH-R2

Target Detection Limit

Achieved Detection Limit

Quality Control Data

$\begin{array}{ll} & \text { Method Blank } \\ & \\ \vec{\Xi} & \text { Matrix Spike } \\ & \text { Concentration Recovered } \\ & \text { Percent Recovery }\end{array}$

$\begin{array}{ll}0.2 U & 0.2 U \\ 200 & \\ 121 & 200 \\ 61 \% & 115\end{array}$

$0.2 \mathrm{U}$

$0.2 U$

200

117

$58 \%$

139

139
$70 \%$

$61 \% \quad 58 \%$

\section{Matrix Spike}

IH-2 Matrix Spike
Concentration Revovered
Percent Recovery

$251 \quad 251$

$\begin{array}{ll}251 & 251 \\ 202 & 185 \\ 80 \% & 74 \%\end{array}$

$$
251
$$

23 \%@(d)

\section{1}

133

\section{1}

IH-3 Matrix Spike

Concentration Revovered

Percent Recovery

$25 i$

139

$50 \%$

$$
\begin{aligned}
& 131 \\
& 47 \%
\end{aligned}
$$

\section{1}

133

$48 \%$

$53 \%$

$\begin{array}{ll}251 & 251 \\ 167 & 160 \\ 61 \% & 59 \%\end{array}$

\section{1}

141

$50 \%$

$0.3 U$
200
146
$73 \%$

Concentration Revovered

Percent Recovery
251

251
128
$47 \%$ \\ 128}

153

$56 \%$
123789 -

$\mathrm{H} \times \mathrm{CDF}$

234678$\mathrm{H} \times \mathrm{CDF}$

1234678- 1234789-

HpCDF HpCDF

OCDF
(a) * Ion ratio out or confirmation ion not detected.
(b) $U$ Not detected at or above detection limit shown.
(c) NA Not applicable.

(d)@ Outside OC criteria range $( \pm 30 \%)$. 
TABLE A.7. Sediment Results and Quality Control Summary for Metals Analyzed by Graphite Furnace Atomic Absorbtion (GFAA), Cold Vapor Atomic Absorption (CVAA), and Inductively Coupled Plasma/Mass Spectrophotometry (ICP/MS), Charleston Intensive Project

Sediment

Treatment

\begin{tabular}{|c|c|c|c|c|c|c|c|c|c|}
\hline & & & & & 3 & & & & \\
\hline $\begin{array}{c}\text { GFAA } \\
\mathrm{Ag}\end{array}$ & $\begin{array}{c}\text { GFAA } \\
\text { As }\end{array}$ & $\begin{array}{r}\text { ICP } \\
\text { Cd }\end{array}$ & $\begin{array}{r}\text { ICP } \\
\mathrm{Cr}\end{array}$ & $\begin{array}{l}\text { ICP } \\
\mathrm{Cu}\end{array}$ & $\begin{array}{c}\text { CVAA } \\
\mathrm{Ha}\end{array}$ & ICP & $\begin{array}{l}\text { ICP } \\
\mathrm{Pb}\end{array}$ & $\begin{array}{c}\text { GFAA } \\
\text { Se }\end{array}$ & ICP \\
\hline
\end{tabular}

Sediment Results

$\mathrm{H}-2$

$\mathrm{IH}-3$

IH-R2

Target Detection Limit

Achieved Detection Limit

$\begin{array}{ll}0.013 U^{(a)} & 3.5 \\ 0.025 & 8.8 \\ 0.013 u & 7.6 \\ & \\ 0.020 & 2.5 \\ 0.013 & 2.5\end{array}$

$\begin{array}{lll}0.016 U & 14.0 \cup & 3.4 \\ 0.036 & 48.9 & 10.0 \\ 0.037 & 33.4 & 6.3\end{array}$

$0.020 \mathrm{U}$

0.035

0.030

\section{9}

9.2
9.3

$0.100 \quad 33.0$

0.016

33.0

5.5

0.010

0.020

7.5

7.5
7.5

5.3
11.2
11.2

$0.128 U \quad 17.3$

$0.149 \quad 36.5$

Quality Control Data

$\vec{N}$ Method Blank

0.021

$N A^{(b)}$

$0.016 U$

NA

NA

$0.02 \mathrm{U}$

NA

6.2

0.243

32.6

Standard Reference Material

Certified
Value 1646
Measured Value 1646
Certified
Value BEST-1
Measured Value
REST-1

$$
\begin{aligned}
& N C^{(c)} \\
& N C
\end{aligned}
$$

$$
\begin{aligned}
& 11.6 \\
& \pm 1.3
\end{aligned}
$$

$\begin{array}{ll}0.360 & 76 \\ \pm 0.07 & \pm 3\end{array}$

0.130

11.8

0.368

74

NC NC

NC NC

NC

NA NA

NC

NC

NC

NA

NA

(a) U Not detected at or above Detection Limit shown.

(b) NA Not applicable.

(c) NC Not certified. 
TABLE A.8. Sediment Butyltin Results, Charleston Intensive Program

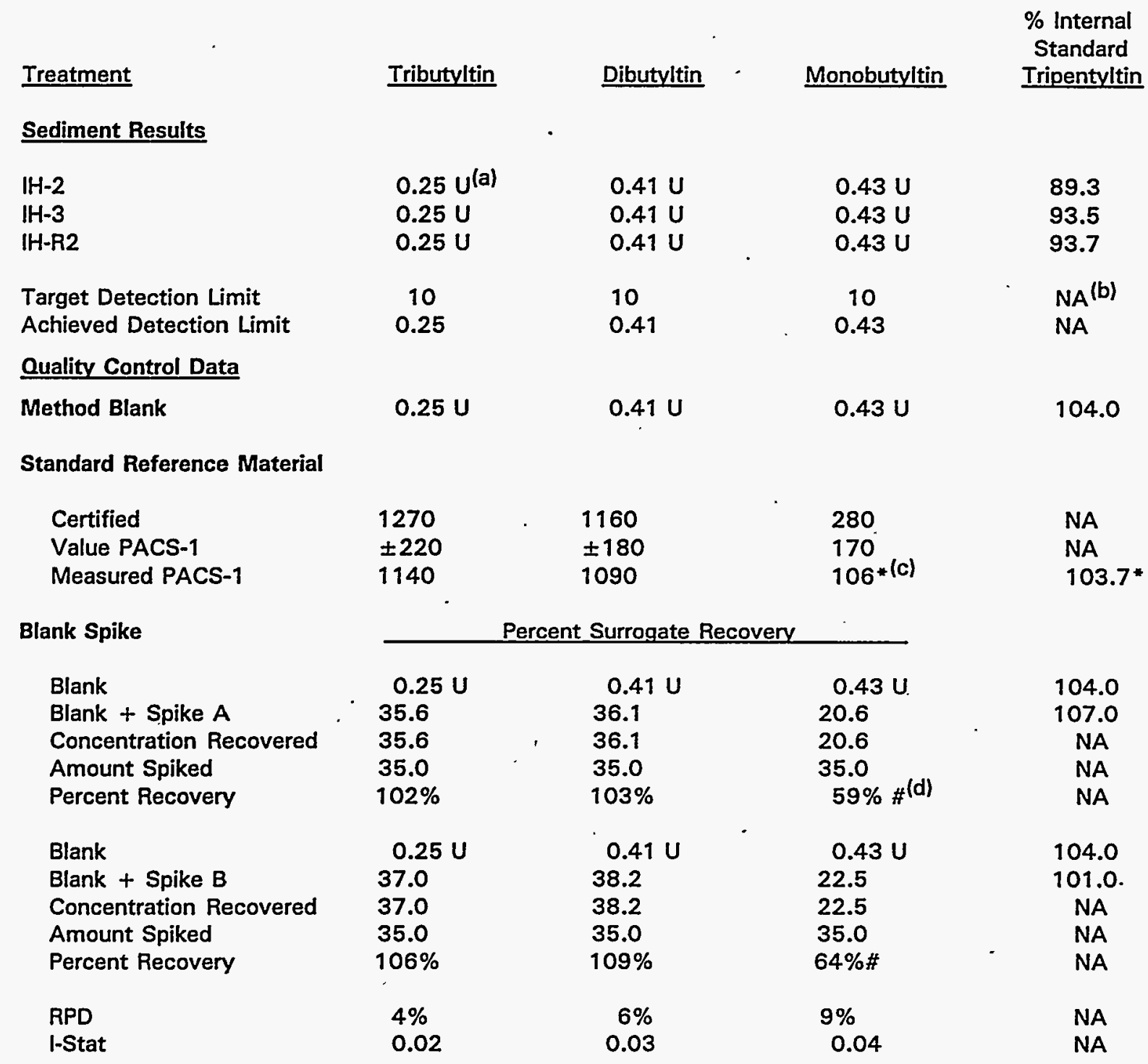

(a) U Not detected at or above Detection Limit shown.

(b) NA Not applicable.

(c) \# Outside QC criteria (70-130\%).

(c) - Outside SRM criteria $( \pm 30 \%)$. 


\section{APPENDIX B}

RINSATE BLANK CHEMISTRY DATA AND QUALITY CONTROL DATA 
TABLE B.1. Rinsate Blank Results and Quality Control Data for Low Molecular Weight Polynuclear Aromatic Hydrocarbons (LPAHs), Charleston Intensive Project

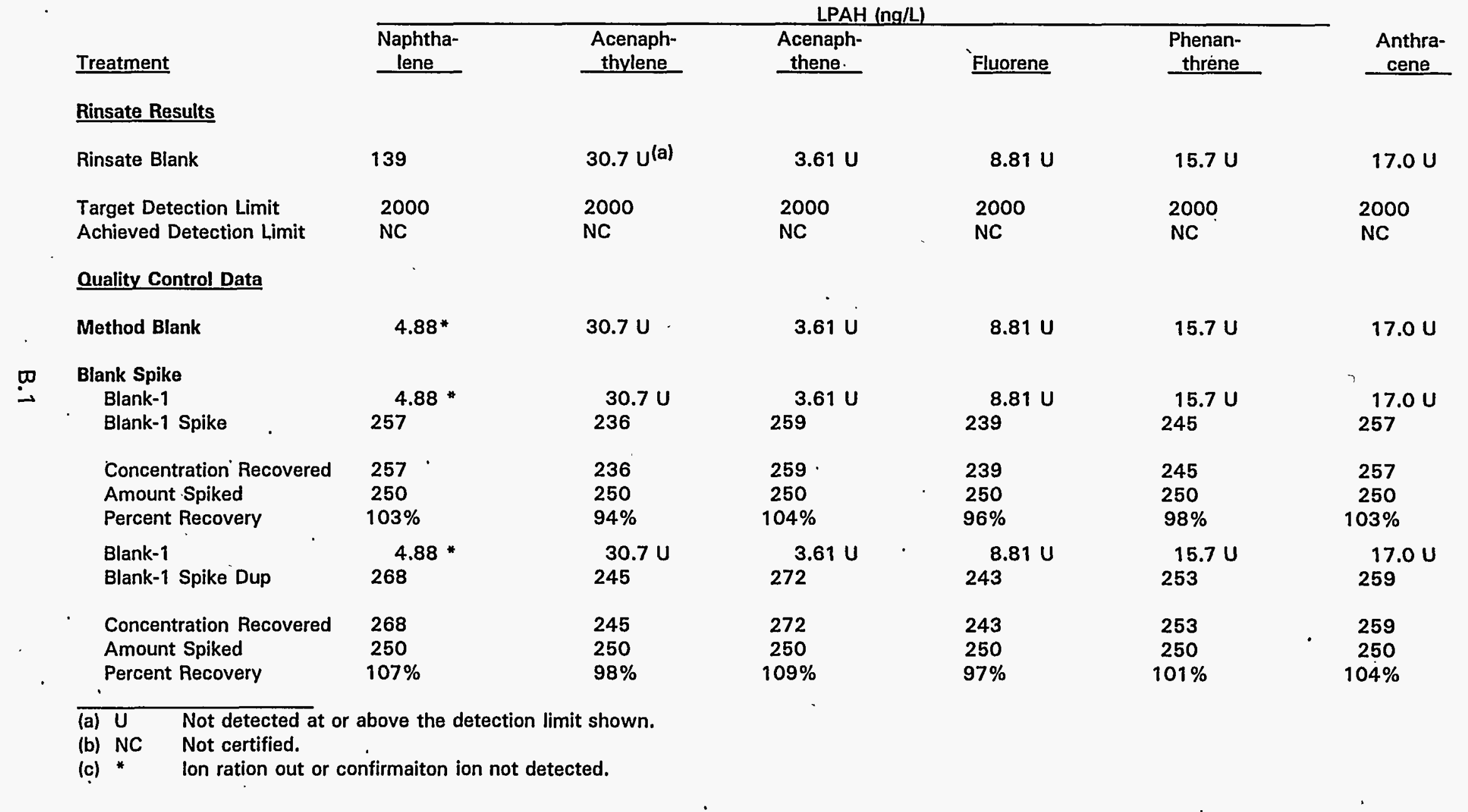


TABLE B.2. Rinsate Blank Results and Quality Control Data for High Molecular Weight Polynuclear Aromatic Hydrocarbons (HPAH), Charleston Intensive Project

\begin{tabular}{|c|c|c|c|c|c|c|c|c|c|c|}
\hline \multirow[b]{2}{*}{ Treatment } & \multicolumn{10}{|c|}{ HPAH (ng/L) } \\
\hline & $\begin{array}{c}\text { Fluor- } \\
\text { anthene }\end{array}$ & Pyrene & $\begin{array}{c}\text { Benzo(a)- } \\
\text { anthra- } \\
\text { cene } \\
\end{array}$ & Chrysene & $\begin{array}{c}\text { Benzo(b)- } \\
\text { fluor- } \\
\text { anthene }\end{array}$ & $\begin{array}{l}\text { Benzo(k)- } \\
\text { fluor- } \\
\text { anthene } \\
\end{array}$ & $\begin{array}{c}\text { Benzo(a) } \\
\text { pyrene }\end{array}$ & $\begin{array}{c}\text { Indeno- } \\
(1,2,3- \\
\text {-cd) } \\
\text { pyrene }\end{array}$ & $\begin{array}{c}\text { Dibenzo- } \\
(a, h) \\
\text { anthra- } \\
\text { cene } \\
\end{array}$ & $\begin{array}{c}\text { Benzo- } \\
(g, h, i) \\
\text { perylene }\end{array}$ \\
\hline \multicolumn{11}{|l|}{ Rinsate Results } \\
\hline Rinsate Blank & $8.71 u^{(a)}$ & $7.93 \mathrm{U}$ & $22.2 *(b)$ & $3.42 U$ & $14.5 U$ & $14.8 \mathrm{U}$ & $7.5 \mathrm{U}$ & $11.8 \mathrm{U}$ & $13.1 \mathrm{U}$ & $11.4 \mathrm{U}$ \\
\hline $\begin{array}{l}\text { Target Detection Limit } \\
\text { Achieved Detection Limit }\end{array}$ & $\begin{array}{l}2000 \\
N C^{(c)}\end{array}$ & $\begin{array}{l}2000 \\
\text { NC }\end{array}$ & $\begin{array}{l}2000 \\
N C\end{array}$ & $\begin{array}{c}2000 \\
\text { NC }\end{array}$ & $\begin{array}{l}2000 \\
\text { NC }\end{array}$ & $\begin{array}{l}2000 \\
\text { NC }\end{array}$ & $\begin{array}{l}2000 \\
\text { NC }\end{array}$ & $\begin{array}{c}2000 \\
\text { NC }\end{array}$ & $\begin{array}{l}2000 \\
\text { NC }\end{array}$ & $\begin{array}{c}2000 \\
\text { NC }\end{array}$ \\
\hline \multicolumn{11}{|l|}{ Quality Control Data } \\
\hline Method Blank & $8.71 \mathrm{U}$ & $7.93 \mathrm{U}$ & $22.1^{*}$ & $3.42 \mathrm{U}$ & $14.5 \mathrm{U}$ & $14.8 \mathrm{U}$ & $7.51 \mathrm{U}$ & $12.2^{*}$ & $13.1 \mathrm{U}$ & $11.4 \mathrm{U}$ \\
\hline \multicolumn{11}{|l|}{ Blank Spike } \\
\hline $\begin{array}{l}\text { Blank-1 } \\
\text { Blank-1 Spike }\end{array}$ & $\begin{array}{l}8.71 U \\
218\end{array}$ & $\begin{array}{l}7.93 \mathrm{U} \\
187\end{array}$ & $\begin{array}{l}22.1 * \\
221\end{array}$ & $\begin{array}{l}3.42 U \\
203\end{array}$ & $\begin{array}{l}14.5 \mathrm{U} \\
221\end{array}$ & $\begin{array}{l}14.8 U \\
219\end{array}$ & $\begin{array}{l}7.51 \mathrm{U} \\
211\end{array}$ & $\begin{array}{l}12.2^{*} \\
229\end{array}$ & $\begin{array}{l}13.1 \mathrm{U} \\
235\end{array}$ & $\begin{array}{l}11.4 \mathrm{U} \\
220\end{array}$ \\
\hline $\begin{array}{l}\text { Concentration Recovered } \\
\text { Amount Spiked } \\
\text { Percent Recovery }\end{array}$ & $\begin{array}{l}218 \\
250 \\
87 \%\end{array}$ & $\begin{array}{l}187 \\
250 \\
75 \%\end{array}$ & $\begin{array}{l}199 \\
250 \\
80 \%\end{array}$ & $\begin{array}{l}203 \\
250 \\
8^{\prime} 1 \%\end{array}$ & $\begin{array}{l}221 \\
250 \\
88 \%\end{array}$ & $\begin{array}{l}219 \\
69.0 \\
88 \%\end{array}$ & $\begin{array}{l}211 \\
69.0 \\
84 \%\end{array}$ & $\begin{array}{l}229 \\
69.0 \\
92 \%\end{array}$ & $\begin{array}{l}235 \\
69.0 \\
94 \%\end{array}$ & $\begin{array}{l}220 \\
69.0 \\
88 \%\end{array}$ \\
\hline $\begin{array}{l}\text { Blank-1 } \\
\text { Blank-1 Spike Dup }\end{array}$ & $\begin{array}{l}8.71 \mathrm{U} \\
225\end{array}$ & $\begin{array}{l}7.93 \mathrm{U} \\
197\end{array}$ & $\begin{array}{l}22.1 \\
227\end{array}$ & $\begin{array}{l}3.42 \mathrm{U} \\
211\end{array}$ & $\begin{array}{l}14.5 U \\
240\end{array}$ & $\begin{array}{l}14.8 \mathrm{U} \\
236\end{array}$ & $\begin{array}{l}7.51 \mathrm{U} \\
232\end{array}$ & $\begin{array}{l}12.2^{*} \\
241\end{array}$ & $\begin{array}{l}13.1 U \\
244\end{array}$ & $\begin{array}{l}11.4 U \\
231\end{array}$ \\
\hline $\begin{array}{l}\text { Concentration Recovered } \\
\text { Amount Spiked } \\
\text { Percent Recovery }\end{array}$ & $\begin{array}{l}225 \\
250 \\
90 \%\end{array}$ & $\begin{array}{l}197 \\
250 \\
79 \%\end{array}$ & $\begin{array}{l}227 \\
250 \\
91 \%\end{array}$ & $\begin{array}{l}211 \\
250 \\
84 \%\end{array}$ & $\begin{array}{l}240 \\
250 \\
96 \%\end{array}$ & $\begin{array}{l}236 \\
250 \\
94 \%\end{array}$ & $\begin{array}{l}232 \\
250 \\
93 \%\end{array}$ & $\begin{array}{l}241 \\
250 \\
96 \%\end{array}$ & $\begin{array}{l}244 \\
250 \\
98 \%\end{array}$ & $\begin{array}{l}231 \\
250 \\
92 \%\end{array}$ \\
\hline
\end{tabular}

(a) - lon ratio out or confirmation ion not detected.

(b) U Not detected at or above detection limit shown.

(c) NC Not certified. 
TABLE B.3. Rinsate Results and Quality Control Data for Dioxins, Charleston Intensive Project

\begin{tabular}{|c|c|c|c|c|c|c|c|}
\hline \multirow[b]{2}{*}{ Treatment } & \multicolumn{7}{|c|}{ Dioxins (ng/kg dry weight) } \\
\hline & $\begin{array}{l}2378- \\
\text { TCDD }\end{array}$ & $\begin{array}{l}12378- \\
\text { PeCDD } \\
\end{array}$ & $\begin{array}{l}123478- \\
\mathrm{H} \times \mathrm{CDD} \\
\end{array}$ & $\begin{array}{l}123678- \\
\mathrm{H} \times \mathrm{CDD} \\
\end{array}$ & $\begin{array}{l}123789- \\
\mathrm{H} \times \mathrm{CDD} \\
\end{array}$ & $\begin{array}{l}1234678- \\
\text { HpCDD } \\
\end{array}$ & OCDD \\
\hline Sediment Results & & & & & & & . \\
\hline Rinsate Blank & $2.0 u^{(a)}$ & $0.9 \mathrm{U}$ & $0.7 \mathrm{U}$ & $2.0 \mathrm{U}$ & $1.2 \mathrm{U}$ & 4.58 & 21.45 \\
\hline $\begin{array}{l}\text { Target Detection Limit } \\
\text { Achieved Detection Limit }\end{array}$ & $\begin{array}{l}20 \\
2.0\end{array}$ & $\begin{array}{l}20 \\
0.9\end{array}$ & $\begin{array}{l}20 \\
0.7\end{array}$ & $\begin{array}{l}20 \\
2.0\end{array}$ & $\begin{array}{l}20 \\
1.2\end{array}$ & $\begin{array}{l}20 \\
0.0\end{array}$ & $\begin{array}{l}20 \\
0.0\end{array}$ \\
\hline Quality Control Data & & & & & & & \\
\hline Blank Spike & & & & & & & \\
\hline $\begin{array}{l}\text { Matrix Spike } \\
\text { Concentration Revovered } \\
\text { Percent Recovery }\end{array}$ & $\begin{array}{l}1932 \\
1267 \\
66 \%\end{array}$ & $\begin{array}{r}1932 \\
1242 \\
64 \%\end{array}$ & $\begin{array}{r}1932 \\
1276 \\
66 \%\end{array}$ & $\begin{array}{l}1932 \\
1220 \\
63 \%\end{array}$ & $\begin{array}{r}1932 \\
1044 \\
54 \%\end{array}$ & $\begin{array}{r}1932 \\
1878 \\
49 \%\end{array}$ & $\begin{array}{l}\text { NA } \\
\text { NA } \\
\text { NA }\end{array}$ \\
\hline
\end{tabular}

(a) U Not detected at or above detection limit shown.

(b) NA Not applicable. 
TABLE B.4. Rinsate Blank Results and Quality Control Data for Furans, Charleston Intensive Project

Furans (ng/kg dry weight)

Treatment

2378- 12378- 23478- $123478-\quad 123678-\quad 123789-$

234678- 1234678- 1234789TCDF PeCDF PeCDF HXCDF HXCDF HXCDF

HxCDF HpCDF HpCDF

$\underline{\mathrm{OCDF}}$

Rinsate Results

Rinsate Blank

$1.7 u^{(a)}$

$0.7 U \cdot 0.8 U$

$2.7 * U^{(b)}$

$2.3^{*} \mathrm{U}$

2.67

$0.7 \mathrm{U}$

$12.8 * U$

$1.2 U$

2.71

Target Detection Limit

1.0
1.7

1.0

1.0

1.0

1.0

1.0

Achieved Detection Limit

0.7

2.7

2.3

0.0

1.0

$1.0 \quad 1.0$

1.0

Quality Control Data

Method Blank

$1.7 \mathrm{U}$

$0.7 U$

$0.8 U$

$2.7 \mathrm{U}$

$2.3 \mathrm{U}$

0.33

$0.7 \mathrm{U}$

$12.8 U$

$1.2 \mathrm{U}$

0.67

$\varpi$

Matrix Spike

Matrix Spike

Concentration Revovered

Percent Recovery

1932

1225

1932

1258

1932

826

1932

403

$21 \%$ @(d)
1932

1269

66\%:

(a) U Not detected at or above detection limit shown.

(b) - Ion ratio out or confirmation ion not detected.

(c) NA Not applicable.

(d) @ Outside OC criteria range $( \pm 30 \%)$. 
TABLE B.5. Rinsate Blank Results and Quality Control Summary for Metals Analyzed by Graphite Furnace Atomic Absorption (GFAA), Cold Vapor Atomic Absorption (CVAA), and Inductively Coupled Plasma/Mass Spectrophotometry (ICP/MS), Charleston Intensive Project

\begin{tabular}{|c|c|c|c|c|c|c|c|c|c|c|}
\hline \multirow{2}{*}{ Treatment } & \multicolumn{9}{|c|}{ Metals $(\mu \mathrm{g} / \mathrm{L})$} & \multirow[b]{2}{*}{$\begin{array}{l}\mathrm{ICP} \\
\mathrm{Zn} \\
\end{array}$} \\
\hline & $\begin{array}{r}\text { GFAA } \\
\mathbf{A g} \\
\end{array}$ & $\begin{array}{r}\text { GFAA } \\
\text { As } \\
\end{array}$ & $\begin{array}{r}\text { ICP } \\
\text { Cd } \\
\end{array}$ & $\begin{array}{r}\mathrm{ICP} \\
\mathrm{Cr} \\
\end{array}$ & $\begin{array}{l}\mathrm{ICP} \\
\mathrm{Cu} \\
\end{array}$ & $\begin{array}{c}\text { CVAA } \\
\mathrm{Hg}\end{array}$ & $\begin{array}{l}\mathrm{ICP} \\
\mathrm{Ni} \\
\end{array}$ & $\begin{array}{l}\text { ICP'. } \\
\mathrm{Pb}\end{array}$ & $\begin{array}{c}\text { GFAA } \\
\text { Se } \\
\end{array}$ & \\
\hline \multicolumn{11}{|l|}{ Results } \\
\hline Rinsate Blank & 0.012 & 0.043 & $0.006 U^{(a)}$ & 0.110 & 0.718 & $0.0002 \mathrm{U}$ & 0.50 & 0.045 & 0.386 & 0.209 \\
\hline $\begin{array}{l}\text { Target Detection Limit } \\
\text { Achieved Detection Limit }\end{array}$ & $\begin{array}{l}0.02 \\
0.005\end{array}$ & $\begin{array}{l}0.043 \\
\text { ND }(b)\end{array}$ & $\begin{array}{l}0.006 \\
0.005\end{array}$ & $\begin{array}{l}0.110 \\
\text { ND }\end{array}$ & $\begin{array}{l}5.5 \\
0.02\end{array}$ & $\begin{array}{l}0.011 \\
0.0002\end{array}$ & $\begin{array}{l}7.5 \\
0.02\end{array}$ & $\begin{array}{l}6.2 \\
0.02\end{array}$ & $\begin{array}{l}0.200 \\
\text { ND }\end{array}$ & $\begin{array}{l}7.8 \\
\text { ND }\end{array}$ \\
\hline \multicolumn{11}{|l|}{ Quality Control Data } \\
\hline Method Blank & 0.002 & 0.02 & 0.004 & 0.044 & 0.027 & $0.0002 \mathrm{U}$ & 0.03 & 0.007 & 0.067 & 0.081 \\
\hline \multicolumn{11}{|l|}{ Standard Reference Material } \\
\hline $\begin{array}{l}\text { Certified } \\
\text { Value } 1643 \mathrm{c}\end{array}$ & $\begin{array}{l}2.21 \\
\pm 0.30\end{array}$ & $\begin{array}{l}82.1 \\
\pm 1.2\end{array}$ & $\begin{array}{l}12.2 \\
\pm 1.0\end{array}$ & $\begin{array}{l}19.0 \\
\pm 0.6\end{array}$ & $\begin{array}{l}22.3 \\
\pm 0.8\end{array}$ & $\begin{array}{l}\mathrm{NC}(\mathrm{c}) \\
\mathrm{NC}\end{array}$ & $\begin{array}{l}60.6 \\
\pm 7.3\end{array}$ & $\begin{array}{l}35.3 \\
\pm 0.9\end{array}$ & $\begin{array}{l}12.7 \\
\pm 0.7\end{array}$ & $\begin{array}{l}73.9 \\
\pm 0.9\end{array}$ \\
\hline Measured Value $1643 \mathrm{c}$ & 2.44 & 83.7 & 12.8 & 22.0 & 20.9 & $N A^{(d)}$ & 62.2 & 34.2 & 12.8 & 77.3 \\
\hline Certified & NC & NC & NC & NC & NC & 1520 & NC & NC & NC & NC \\
\hline Value BEST-1 & NC & NC & NC & NC & NC & \pm 40 & NC & NC & NC & NC \\
\hline $\begin{array}{l}\text { Measured Value } \\
\text { BEST-1 }\end{array}$ & NA & NA & NA & NA & NA & 1630 & NA & NA & NA & NA \\
\hline
\end{tabular}

\footnotetext{
(a) U Not detected at or above Detection Limit shown.

(b) ND Not determined.

(c) NC Not certified.

(d) NA Not applicable.
} 
TABLE B.6. Rinsate Blank Butyltin Results, Charleston Intensive Program

\begin{tabular}{|c|c|c|c|c|}
\hline Treatment & Tributyltin & Dibutyltin & Monobutyltin & $\begin{array}{l}\text { \% Interna } \\
\text { Standarc } \\
\text { Tripentyltin }\end{array}$ \\
\hline \multicolumn{5}{|l|}{ Rinsate Results } \\
\hline Rinsate Blank & $0.25 u^{(a)}$ & 29.1 & $0.43 \mathrm{U}$ & 99.7 \\
\hline $\begin{array}{l}\text { Target Detection Limit } \\
\text { Achieved Detection Limit }\end{array}$ & $\begin{array}{l}10 \\
0.25\end{array}$ & $\begin{array}{l}10 \\
0.41\end{array}$ & $\begin{array}{l}10 \\
0.43\end{array}$ & $\begin{array}{l}N A^{(b)} \\
N A\end{array}$ \\
\hline \multicolumn{5}{|l|}{ Quality Control Data } \\
\hline Method Blank & $0.25 \mathrm{U}$ & $0.41 U$ & $0.43 U$ & 104.9 \\
\hline
\end{tabular}

(a) U Not detected at or above Detection Limit shown.

(b) NA Not applicable.

B. 6 
APPENDIX C

96-HOUR N. beryllina SUSPENDED-PARTICULATE-PHASETEST 
TABLE C.1. Results for All Replicates in 96-h M. beryllina SuspendedParticulate-Phase Test, Charleston Intensive Project

\section{Sediment \\ Treatment}

$\mathrm{IH}-2$

$\mathrm{IH}-2$

$\mathrm{IH}-2$

$\mathrm{IH}-2$

$\mathrm{IH}-2$

$\mathrm{HH}-2$

$\mathrm{IH}-2$

$\mathrm{IH}-2$

$\mathrm{IH}-2$

$\mathrm{IH}-2$

$\mathrm{HH}-2$

IH-2

IH-2

$\mathrm{IH}-2$

IH-2

$\mathrm{IH}-2$

$\mathrm{IH}-2$

IH-2

$\mathrm{IH}-2$

$\mathrm{IH}-2$

IH-3

IH-3

IH-3

IH-3

$\mathrm{IH}-3$

IH-3

IH-3

$\mathrm{IH}-3$

IH-3

IH-3

IH-3

IH-3

$\mathrm{IH}-3$.

IH-3

IH-3

IH-3

$\mathrm{IH}-3$

$\mathrm{IH}-3$

$\mathrm{IH}-3$

$\mathrm{IH}-3$

\section{Concentration \\ (Percent SPP)}

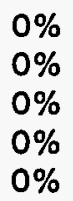

$10 \%$

$10 \%$

$10 \%$

$10 \%$

$10 \%$

$50 \%$

$50 \%$

$50 \%$

$50 \%$

$50 \%$

$100 \%$

$100 \%$

$100 \%$

$1.00 \%$

$100 \%$

$0 \%$

$0 \%$

$0 \%$

$0 \%$

$0 \%$

$10 \%$

$10 \%$

$10 \%$

$10 \%$

$10 \%$

$50 \%$

$50 \%$

$50 \%$

$50 \%$

$50 \%$

$100 \%$

$100 \%$

$100 \%$

$100 \%$

$100 \%$
Replicate

1
2
3
4
5

1

2

3

4

5

1

2

3

4

5

1

2

3

4

5

1

2

3

4

1

1
2

3

4

5

1

2

\section{3}

4

$$
5
$$

1

\section{2}

3

4

\section{Alive}

8
9
10
9
9

Dead

2
1
0
1
1

90.0

82

91

9

9

9

88.0

$\begin{array}{ll}9 & 1\end{array}$

82

9,1

9 - 1

91

88.0

$9 \quad 1$

82

9

10

10

92.0

92.0

86.0

1$$
86.0
$$

73

$8 \quad 2$

\section{9}

8
7

78.0

$\begin{array}{ll}8 & 2 \\ 7 & 3 \\ 9 & 1 \\ 5 & 5 \\ 7 & 3\end{array}$

72.0 
TABLE C.2 Water Quality Summary for 48-h M. beryllina Suspended-Particulate-Phase Test, Charleston Intensive Project

\begin{tabular}{|c|c|c|c|c|c|c|c|c|c|}
\hline \multirow{2}{*}{$\begin{array}{l}\text { Sediment } \\
\text { Treatment }\end{array}$} & \multirow{2}{*}{$\begin{array}{l}\text { Concentration } \\
\text { (Percent SPP) }\end{array}$} & \multicolumn{2}{|c|}{$\begin{array}{c}\text { Temperature } \\
\left({ }^{\circ} \mathrm{C}\right)\end{array}$} & \multicolumn{2}{|c|}{$\mathrm{pH}$} & \multicolumn{2}{|c|}{$\begin{array}{c}\text { Dissolved } \\
\text { Oxygen } \\
\text { (mg/L) }\end{array}$} & \multicolumn{2}{|c|}{$\begin{array}{r}\text { Salinity } \\
\text { (ppt) }\end{array}$} \\
\hline & & Min & Max & Min & Max & Min & Max & Min & $\operatorname{Max}$ \\
\hline \multicolumn{2}{|c|}{ Acceptable Range } & 18.0 & 22.0 & 7.50 & 8.50 & 5.0 & $N A^{(a)}$ & 28.0 & 32.0 \\
\hline $\mathrm{H}-2$ & 0 & 19.8 & 20.4 & 7.91 & 8.23 & 7.0 & 8.0 & 29.0 & 30.0 \\
\hline $\mathrm{HH}-2$ & 10 & 19.8 & 20.4 & 7.87 & 8.19 & 7.1 & 8.0 & 28.5 & 30.0 \\
\hline $\mathrm{IH}-2$ & 50 & 19.8 & 20.3 & 7.78 & 8.20 & 6.4 & 8.1 & 29.0 & 30.0 \\
\hline $\mathrm{HH}-2$ & 100 & 19.8 & 20.3 & 7.75 & 8.15 & 7.1 & 7.8 & 29.5 & 30.0 \\
\hline $\mathrm{IH}-3$ & 0 & 19.7 & 20.6 & 7.85 & 8.17 & 6.9 & 8.0 & 30.0 & 30.5 \\
\hline $\mathrm{IH}-3$ & 10 & 19.7 & 20.6 & 7.84 & 8.16 & 6.9 & 8.0 & 29.0 & 30.5 \\
\hline $\mathrm{IH}-3$ & 50 & 19.6 & 20.6 & 7.80 & 8.24 & 7.0 & 7.8 & 28.5 & 30.0 \\
\hline $\mathrm{IH}-3$ & 100 & 19.7 & 20.5 & 7.79 & 8.30 & 6.9 & 7.6 & 28.0 & 30.0 \\
\hline
\end{tabular}

(a) NA Not applicable. 
TABLE C.3. Results for All Replicates in 96-h M. beryllina Reference Toxicant Test, Charleston Intensive Project

\begin{tabular}{|c|c|c|c|c|}
\hline 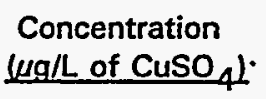 & Replicate & Alive & Dead & $\begin{array}{l}\text { Percent } \\
\text { Survival } \\
\end{array}$ \\
\hline 0 & 1 & 10 & 0 & \\
\hline 0 & 2 & 8 & 2 & \\
\hline 0 & 3. & 9 & 1 & $90.0 \%$ \\
\hline 16 & 1 & 10 & 0 & \\
\hline 16 & 2 & 8 & 2 & \\
\hline 16 & 3 & 10 & 0 & $93.3 \%$ \\
\hline 64 & 1 & 8 & 2 & \\
\hline 64 & 2 & 7 & 3 & \\
\hline 64 & 3 & 9 & 1 & $80.0 \%$ \\
\hline 160 & 1 & 0 & 10 & \\
\hline 160 & 2 & 0 & 10 & \\
\hline 160 & 3 & 0 & 10 & $0.0 \%$ \\
\hline 400 & 1 & 0 & 10 & \\
\hline 400 & 2 & 0 & 10 & $\cdot$ \\
\hline 400 & 3 & 0 & 10 & $0.0 \%$ \\
\hline
\end{tabular}


TABLE C.4. Water Quality Summary for 96-h M. beryllina Reference Toxicant Test, Charleston Intensive Project

\begin{tabular}{|c|c|c|c|c|c|c|c|c|}
\hline \multirow{2}{*}{$\begin{array}{l}\text { Concentration } \\
\left(\mu \mathrm{g} / \mathrm{L} \mathrm{CuSO}_{4} L\right.\end{array}$} & \multicolumn{2}{|c|}{$\begin{array}{c}\text { Temperature } \\
\text { (० } \mathrm{C}) \\
\end{array}$} & \multicolumn{2}{|c|}{$\mathrm{pH}$} & \multicolumn{2}{|c|}{$\begin{array}{c}\text { Dissolved } \\
\text { Oxygen } \\
\text { (mg/L) }\end{array}$} & \multicolumn{2}{|c|}{$\begin{array}{c}\text { Salinity } \\
\text { (ppt) }\end{array}$} \\
\hline & Min & Max & Min & Max & Min & Max & Min & Max \\
\hline Acceptable Range & 18.0 & 22.0 & 7.50 & 8.50 & 5.0 & $N A^{(a)}$ & 28.0 & 32.0 \\
\hline 0.0 & 20.1 & 20.8 & 7.86 & 8.13 & 6.9 & 7.8 & 29.5 & 31.5 \\
\hline 16.0 & 20.0 & 20.9 & 7.91 & 8.19 & 7.0 & 7.7 & 30.0 & 30.5 \\
\hline 64.0 & 20.1 & 20.8 & 7.86 & 8.17 & 7.0 & 8.0 & 30.0 & 30.5 \\
\hline 160.0 & 20.1 & 20.4 & 7.90 & 8.16 & 7.3 & 7.8 & 30.0 & 30.0 \\
\hline 400.0 & 20.1 & 20.3 & 7.90 & 8.09 & 7.3 & 7.8 & 30.0 & 30.0 \\
\hline
\end{tabular}

(a) NA Not applicable. 
APPENDIX D

96-HOUR M. bahia SUSPENDED-PARTICULATE-PHASETEST 
TABLE D.1. Results for All Replicates in 96-h M. bahia Suspended-Particulate-Phase Test, Charleston Intensive Project

\begin{tabular}{|c|c|c|c|c|c|}
\hline $\begin{array}{l}\text { Sediment } \\
\text { Treatment }\end{array}$ & $\begin{array}{l}\text { Concentration } \\
\text { (Percent SPP) }\end{array}$ & Replicate & Alive & Dead & $\begin{array}{l}\text { Percent } \\
\text { Survival }\end{array}$ \\
\hline $\mathbb{H}-2$ & $0 \%$ & 1 & 10 & 0 & \\
\hline $\mathrm{IH}-2$ & $0 \%$ & 2 & 10 & 0 & \\
\hline $\mathbb{H}-2$ & $0 \%$ & 3 & 9 & 1 & \\
\hline $\mathrm{IH}-2$ & $0 \%$ & 4 & 10 & 0 & \\
\hline $\mathbb{I H}-2$ & $0 \%$ & 5 & 10 & 0 & 98.0 \\
\hline $\mathbb{H}-2$ & $10 \%$ & 1 & 8 & 2 & \\
\hline $\mathrm{IH}-2$ & $10 \%$ & 2 & 10 & 0 & \\
\hline $\mathrm{IH}-2$ & $10 \%$ & 3 & 8 & 2 & \\
\hline $\mathrm{HH}-2$ & $10 \%$ & 4 & 7 & 3 & \\
\hline $\mathbb{I H}-2$ & $10 \%$ & 5 & 9 & 1 & 84.0 \\
\hline $\mathrm{IH}-2$ & $50 \%$ & 1 & 9 & 1 & \\
\hline $\mathrm{H}-2$ & $50 \%$ & 2 & 10 & 0 & \\
\hline $\mathrm{IH}-2$ & $50 \%$ & 3 & 10 & 0 & \\
\hline $\mathrm{HH}-2$ & $50 \%$ & 4 & 9 & 1 & \\
\hline $\mathrm{HH}-2$ & $50 \%$ & 5 & 8 & 2 & 92.0 \\
\hline $\mathrm{HH}-2$ & $100 \%$ & 1 & 8 & 2 & \\
\hline $\mathrm{HH}-2$ & $100 \%$ & 2 & 10 & 0 & \\
\hline $\mathrm{HH}-2$ & $100 \%$ & 3 & 9 & 1 & \\
\hline $\mathrm{HH}-2$ & $100 \%$ & 4 & 9 & 1 & \\
\hline $\mathrm{HH}-2$ & $100 \%$ & 5 & 7 & 3 & 86.0 \\
\hline $\mathrm{IH}-3$ & $0 \%$ & 1 & 8 & 2 & \\
\hline $\mathrm{HH}-3$ & $0 \%$ & 2 & 9 & 1 & \\
\hline $\mathrm{HH}-3$ & $0 \%$ & 3 & 8 & 2 & \\
\hline $\mathrm{HH}-3$ & $0 \%$ & 4 & 10 & 0 & \\
\hline $\mathbb{H H}-3$ & $0 \%$ & 5 & 10 & 0 & 90.0 \\
\hline IH-3 & $10 \%$ & 1 & 9 & 1 & \\
\hline $\mathrm{H}-3$ & $10 \%$ & 2 & 10 & 0 & \\
\hline $\mathrm{H}-3$ & $10 \%$ & 3 & 9 & 1 & \\
\hline $\mathrm{HH}-3$ & $10 \%$ & 4 & 10 & 0 & \\
\hline $\mathrm{HH}-3$ & $10 \%$ & 5 & 8 & 2 & 92.0 \\
\hline IH-3 & $50 \%$ & 1 & 10 & 0 & \\
\hline $\mathrm{IH}-3$ & $50 \%$ & 2 & 10 & 0 & \\
\hline $\mathrm{IH}-3$ & $50 \%$ & 3 & 9 & 1 & • \\
\hline $\mathrm{IH}-3$ & $50 \%$ & 4 & 9 & 1 & \\
\hline $\mathrm{HH}-3$ & $50 \%$ & 5 & 9 & 1 & 94.0 \\
\hline $\mathrm{HH}-3$ & $100 \%$ & 1 & 10 & 0 & \\
\hline $\mathbb{H H}-3$ & $100 \%$ & 2 & 10 & 0 & \\
\hline $\mathbb{H} H-3$ & $100 \%$ & 3 & 8 & 2 & \\
\hline $\mathrm{HH}-3$ & $100 \%$ & 4 & 9 & 1 & \\
\hline $\mathrm{IH}-3$ & $100 \%$ & 5 & 8 & 2 & 90.0 \\
\hline
\end{tabular}


TABLE D.2. Results for All Replicates in 96-h M. bahia Reference Toxicant Test, Charleston Intensive Project

\begin{tabular}{|c|c|c|c|c|}
\hline 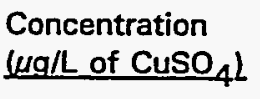 & Replicate & Alive & Dead & $\begin{array}{l}\text { Percent } \\
\text { Survival } \\
\end{array}$ \\
\hline 0 & 1 & 10 & 0 & \\
\hline 0 & 2 & 10 & 0 & \\
\hline 0 & 3 & 9 & 1 & $97.0 \%$ \\
\hline 50 & 1 & 8 & 2 & \\
\hline 50 & 2 & 10 & 0 & \\
\hline 50 & 3 & 9 & 1 & $90.0 \%$ \\
\hline 100 & 1 & 8 & 2 & \\
\hline 100 & 2 & 8 & 2 & \\
\hline 100 & 3 & 8 & 2 & $80.0 \%$ \\
\hline 150 & 1 & 10 & 0 & \\
\hline 150 & 2 & 10 & 0 & \\
\hline 150 & 3 & 9 & 1 & $97.0 \%$ \\
\hline 300 & 1 & 5 & 5 & \\
\hline 300 & 2 & 4 & 6 & \\
\hline 300 & 3 & 4 & 6 & $43.3 \%$ \\
\hline
\end{tabular}

D.2 
TABLE D.3. Results for All Replicates in 96-h M. bahia Reference Toxicant Test, Charleston Intensive Project

\begin{tabular}{|c|c|c|c|c|}
\hline $\begin{array}{l}\text { Concentration } \\
(\mu \mathrm{g} / \mathrm{L} \text { of CuSO} \\
\end{array}$ & Replicate & Alive & Dead & $\begin{array}{l}\text { Percent } \\
\text { Survival }\end{array}$ \\
\hline 0 & 1 & 10 & 0 & \\
\hline 0 & 2 & 10 & 0 & \\
\hline 0 & 3 & 9 & 1 & $97.0 \%$ \\
\hline 50 & 1 & 8 & 2 & \\
\hline 50 & 2 & 10 & 0 & \\
\hline 50 & 3 & 9 & 1 & $90.0 \%$ \\
\hline 100 & 1 & 8 & 2 & \\
\hline 100 & 2 & 8 & 2 & \\
\hline 100 & 3 & 8 & 2 & $80.0 \%$ \\
\hline 150 & 1 & 10 & 0 & \\
\hline 150 & 2 & 10 & 0 & \\
\hline 150 & 3 & 9 & 1 & $97.0 \%$ \\
\hline 300 & 1 & 5 & 5 & \\
\hline 300 & 2 & 4 & 6 & \\
\hline 300 & 3 & 4 & 6 & $43.3 \%$ \\
\hline
\end{tabular}

D:3 
TABLE D.4. Water Quality Summary for 48-h M. bahia Reference Toxicant Test, Charleston Intensive Project

\begin{tabular}{|c|c|c|c|c|c|c|c|c|}
\hline \multirow{2}{*}{$\begin{array}{l}\text { Concentration } \\
(\mu \mathrm{g} / \mathrm{L} \mathrm{CuSO})_{4}\end{array}$} & \multicolumn{2}{|c|}{$\begin{array}{c}\text { Temperature } \\
\left({ }^{\circ} \mathrm{C}\right) \\
\end{array}$} & \multicolumn{2}{|c|}{$\mathrm{pH}$} & \multicolumn{2}{|c|}{$\begin{array}{c}\text { Dissolved } \\
\text { Oxygen } \\
\text { (mg/L) }\end{array}$} & \multicolumn{2}{|c|}{$\begin{array}{l}\text { Salinity } \\
\text { (ppt) }\end{array}$} \\
\hline & Min & Max & Min & Max & Min & Max & Min & $\operatorname{Max}$ \\
\hline Acceptable Range & 18.0 & 22.0 & 7.50 & 8.50 & 5.0 & $N A^{(a)}$ & 28.0 & 32.0 \\
\hline 0.0 & 19.6 & 20.3 & 8.08 & 8.17 & 7.2 & 7.6 & 30.0 & 32.0 \\
\hline 50.0 & 19.6 & 20.4 & 8.02 & 8.18 & 7.4 & 7.6 & 30.0 & 31.5 \\
\hline 100.0 & 19.6 & 20.4 & 8.07 & 8.15 & 7.4 & 7.7 & 30.0 & 31.5 \\
\hline 150.0 & 19.7 & 20.4 & 7.98 & 8.12 & 7.4 & 7.7 & 30.5 & 31.0 \\
\hline 300.0 & 19.6 & 20.3 & 8.01 & 8.19 & 7.4 & 7.6 & 30.0 & 31.5 \\
\hline
\end{tabular}

(a) NA Not applicable. 


\section{APPENDIXE}

\section{8-HOUR L. pictUS SUSPENDED-PARTICULATE-PHASETEST}


• 
TABLE E.1. Results for All Replicates in 48-h L. pictus Suspended-Particulate-Phase Test, Charleston Intensive Project

\begin{tabular}{|c|c|c|c|c|c|c|c|c|c|c|}
\hline $\begin{array}{c}\begin{array}{c}\text { Concentration } \\
(\% \text { SPP })\end{array} \\
\end{array}$ & Replicate & $\begin{array}{l}\text { Normal } \\
\text { Pluteus }\end{array}$ & $\begin{array}{c}\text { Abnormal } \\
\text { Pluteus }\end{array}$ & Other & $\begin{array}{l}\text { Percent } \\
\text { Normal }\end{array}$ & $\begin{array}{l}\text { Percent } \\
\text { Survival }\end{array}$ & $\begin{array}{l}\text { Mean \% } \\
\text { Normal }\end{array}$ & $\begin{array}{l}\text { Standard } \\
\text { Deviation }\end{array}$ & $\begin{array}{l}\text { Mean \% } \\
\text { Survival }\end{array}$ & $\begin{array}{l}\text { Standard } \\
\text { Deviation }\end{array}$ \\
\hline \multicolumn{11}{|l|}{ Station IH-2 } \\
\hline 0 & 1 & 266 & 1 & 14 & 91.9 & 97.0 & & & & \\
\hline 0 & 2 & 255 & 3 & 14 & 88.1 & 93.9 & & & & \\
\hline 0 & 3 & 249 & 0 & 18 & 86.0 & 92.2 & & & & \\
\hline 0 & 4 & .294 & 2 & 13 & 100.0 & 100.0 & & & & \\
\hline 0 & 5 & 257 & 1 & 10 & 88.7 & 92.5 & 90.9 & 4.9 & 95.1 & 3.0 \\
\hline 10 & 1 & 203 & 2 & 3 & 70.1 & 71.8 & & & & \\
\hline 10 & 2 & 251 & 1 & 7 & 86.7 & 89.4 & & & & \\
\hline 10 & 3 & 223 & 23 & 9 & 77.0 & 88.1 & & & & \\
\hline 10 & 4 & 228 & 2 & 11 & 78.7 & 83.2 & & & & \\
\hline 10 & 5 & 269 & 6 & 11 & 92.9 & 98.8 & 81.1 & 7.9 & 86.3 & 8.8 \\
\hline 50 & 1 & 234 & 7 & 15 & 80.8 & 88.4 & & & & \\
\hline 50 & 2 & 259 & 4 & 10 & 89.4 & 94.3 & & & .. & \\
\hline 50 & 3 & 237 & 11 & 15 & 81.8 & 90.8 & & & & \\
\hline 50 & 4 & 194 & 25 & 10 & 67.0 & 79.1 & & & & \\
\hline 50 & -5 & 233 & 2 & 11 & 80.5 & 84.9 & 79.9 & 7.2 & 87.5 & 5.2 \\
\hline 100 & 1 & 6 & 3 & 236 & 2.1 & 84.6 & & & & · \\
\hline 100 & 2 & 5 & 0 & 250 & 1.7 & 88.1 & & & & \\
\hline 100 & 3 & 0 & 0 & 262 & 0.0 & 90.5 & & & & \\
\hline 100 & 4 & 3 & 1 & 301 & 1.0 & 100.0 & & & & \\
\hline 100 & 5 & 0 & 2 & 306 & 0.0 & 100.0 & 1.0 & 0.9 & 92.6 & 6.3 \\
\hline \multicolumn{11}{|l|}{ Station $1 \mathrm{H}-3$} \\
\hline 0 & 1 & 226 & 4 & 3 & 79.9 & 83.9 & & & & \\
\hline 0 & 2 & 229 & 9 & 11 & 81.0 & 86.0 & & & & \\
\hline 0 & 3 & 244 & 3 & 12 & 86.3 & 89.4 & & & & \\
\hline 0 & 4 & 312 & 4 & 15 & 100.0 & 100.0 & & & & \\
\hline 0 & 5 & 257 & 4 & 11 & 90.9 & 93.9 & 87.6 & 7.3 & 90.6 & 5.8 \\
\hline 10 & 1 & 203 & 2 & 12 & 71.8 & 74.9 & & & & \\
\hline 10 & 2 & 213 & 2 & 10 & 75.3 & 77.7 & & & & \\
\hline 10 & 3 & 241 & 2 & 10 & 85.2 & 87.4 & & & & \\
\hline 10 & 4 & 262 & 6 & 10 & 92.6 & 96.0 & & & & \\
\hline 10 & 5 & 230 & 0 :- & 2 & 81.3 & 80.1 & 81.3 & 7.4 & 83.2 & 7.6 \\
\hline 50 & 1 & 174 & 2 & 8 & 61.5 & 63.5 & & & & \\
\hline 50 & 2 & 202 & 0 & 11 & 71.4 & 73.5 & & & & \\
\hline 50 & 3 & 222 & 2 & 9 & 78.5 & 80.5 & & & & \\
\hline 50 & 4 & 223 & 0 & 19 & 78.9 & 83.6 & & & & \\
\hline 50 & 5 & 243 & 0 & 5 & 85.9 & 85.6 & 75.2 & 8.3 & 77.3 & 8.0 \\
\hline 100 & 1 & 269 & 0 & 13 & 95.1 & 97.4 & & & & \\
\hline 100 & 2 & 261 & 1 & 10 & 92.3 & 93.9 & & & & \\
\hline 100 & 3 & 238 & 1 & 18 & 84.2 & 88.7 & & & & \\
\hline 100 & 4 & 253 & 0 & 18 & 89.5 & 93.6 & & & & \\
\hline 100 & 5 & 250 & 1 & 15 & 88.4 & 91.9 & 89.9 & 3.7 & 93.1 & 2.8 \\
\hline
\end{tabular}


TABLE E.2. Water Quality Summary for 48-h L. pictus Suspended-Particulate-Phase Test, Charleston Intensive Project

\begin{tabular}{|c|c|c|c|c|c|c|c|c|c|}
\hline \multirow{2}{*}{$\begin{array}{l}\text { Sediment } \\
\text { Treatment }\end{array}$} & \multirow{2}{*}{$\begin{array}{l}\text { Concentration } \\
\text { (Percent SPP) }\end{array}$} & \multicolumn{2}{|c|}{$\begin{array}{c}\text { Temperature } \\
\left({ }^{\circ} \mathrm{C}\right) \\
\end{array}$} & \multicolumn{2}{|c|}{$\mathrm{pH}$} & \multicolumn{2}{|c|}{$\begin{array}{c}\text { Dissolved } \\
\text { Oxygen } \\
\text { (mg/L) }\end{array}$} & \multicolumn{2}{|c|}{$\begin{array}{r}\text { Salinity } \\
\text { (ppt) }\end{array}$} \\
\hline & & Min & Max & $\underline{\text { Min }}$ & Max & Min & Max & Min & Max \\
\hline Acceptable & & 18.0 & 22.0 & 7.50 & 8.50 & 5.0 & $N A^{(a)}$ & 28.0 & 32.0 \\
\hline $\mathrm{HH}-2$ & 0 & 18.8 & 19.8 & 7.39 & 8.12 & 7.3 & 8.0 & 30.5 & 31.5 \\
\hline $\mathrm{IH}-2$ & 10 & 18.8 & 19.8 & 7.45 & 8.15 & 7.2 & 7.8 & 30.0 & 32.0 \\
\hline $\mathrm{IH}-2$ & 50 & 18.7 & 19.9 & 7.41 & 8.11 & 6.5 & 7.4 & 30.0 & 31.5 \\
\hline IH-2 & 100 & 18.7 & 19.9 & 7.24 & 8.26 & 6.3 & 7.5 & 30.0 & 30.0 \\
\hline $\mathrm{IH}-3$ & 0 & 18.8 & 19.9 & 7.41 & 8.11 & 7.7 & 7.8 & 30.0 & 32.0 \\
\hline $\mathrm{IH}-3$ & 10 & 18.8 & 19.9 & 7.52 & 8.11 & 7.6 & 7.8 & 30.5 & 32.0 \\
\hline $\mathbb{H}-3$ & 50 & 18.7 & 19.9 & 7.34 & 8.08 & 7.4 & 7.5 & 30.0 & 32.0 \\
\hline $\mathrm{IH}-3$ & 100 & 18.7 & 19.8 & 7.21 & 8.08 & 6.9 & 7.5 & 30.0 & 31.5 \\
\hline
\end{tabular}

(a) NA Not applicable. 
TABLE E.3. Results for All Replicates in 48-h L. pictus Reference Toxicant Test, Charleston Intensive Project

\begin{tabular}{|c|c|c|c|c|c|c|c|c|c|c|}
\hline $\begin{array}{l}\text { Concentration } \\
(\mu \mathrm{g} / \mathrm{L} \text { of CuSO4) }\end{array}$ & Replicate & $\begin{array}{l}\text { Normal } \\
\text { Pluteus } \\
\end{array}$ & $\begin{array}{l}\text { Abnormal } \\
\text { Pluteus }\end{array}$ & Other & $\begin{array}{l}\text { Percent } \\
\text { Normal }\end{array}$ & $\begin{array}{l}\text { Percent } \\
\text { Survival }\end{array}$ & $\begin{array}{l}\text { Mean \% } \\
\text { Normal }\end{array}$ & $\begin{array}{l}\text { Standard } \\
\text { Deviation }\end{array}$ & $\begin{array}{l}\text { Mean \% } \\
\text { Survival }\end{array}$ & $\begin{array}{l}\text { Standard } \\
\text { Deviation }\end{array}$ \\
\hline 0 & 1 & 277 & 3 & 11 & 96.8 & 100.0 & & & & \\
\hline 0 & 2 & 221 & 4 & 12 & 77.2 & 82.8 & & & & \\
\hline 0 & 3 & 206 & 3 & 8 & 72.0 & 75.8 & 82.0 & 10.7 & 86.8 & 10.9 \\
\hline 3 & 1 & 251 & 6 & 6 & 87.7 & 91.9 & & & & \\
\hline 3 & 2 & 238 & 5 & 15 & 83.2 & 90.1 & & & & \\
\hline 3 & 3 & 250 & 3 & 13 & 87.4 & 92.9 & 86.1 & 2.1 & 91.7 & 1.2 \\
\hline 9 & 1 & 253 & 31 & 9 & 88.4 & 100.0 & & & . & \\
\hline 9 & 2 & 253 & 8 & 13 & 88.4 & 95.7 & & & & \\
\hline 9 & 3 & 217 & 11 & 13 & 75.8 & 84.2 & 84.2 & 5.9 & 94.1 & 7.5 \\
\hline 30 & 1 & 239 . & 51 & 17 & 83.5 & 100.0 & & & & \\
\hline 30 & 2 & 211 & 19 & 17 & 73.7 & 86.3 & & & .. & \\
\hline 30 & 3 & 81 & 179 & 12 & 28.3 & 95.0 & 61.8 & 24.1 & 96.2 & 8.6 \\
\hline 100 & 1 & 3 & 0 & 249 & 1.0 & 88.1 & & 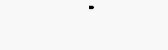 & & \\
\hline 100 & 2 & 1 & 0 & 241 & 0.3 & 84.6 & & & & \\
\hline 100 & 3 & 0 & 0 & 280 & 0.0 & 97.8 & 0.5 & 0.4 & 90.1 & 5.6 \\
\hline
\end{tabular}


TABLE E.4. Water Quality Summary for 48-h L. pictus Reference Toxicant Test, Charleston Intensive Project

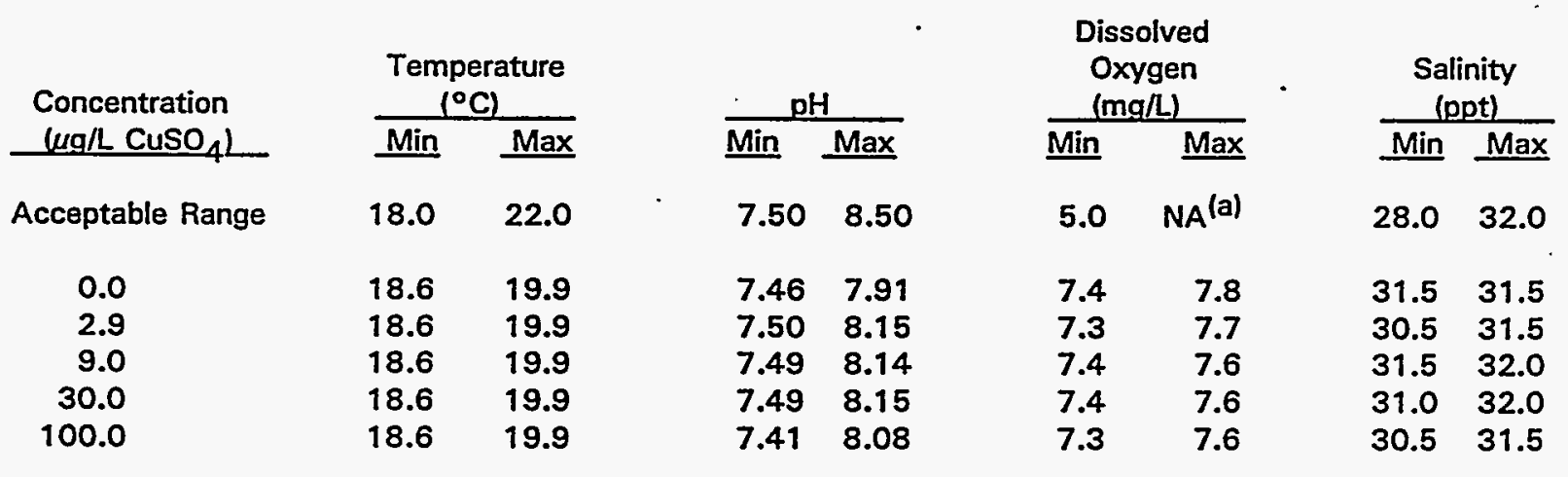

(a) NA Not applicable. 


\section{Distribution}

No. of

Copies

OFFSITE

2 DOE/Office of Scientific and Technical Information

15 R. Coller-Sopcha

U.S. Army Corps of Engineers P.O. Box $919^{\circ}$

Charleston, SC 29402-0919

ONSITE

DOE Richland Operations Office

P. W. Kruger

A5-90
No. of

Copies

15 Pacific Northwest Laboratory

W. W. Gardiner (5)

SEQUI

L. M. Gully

SEQUI

J. A. Ward

SEQUI

J. Q. Word

SEQUI

Publishing Coordination

Technical Report Files (5)

Routing

R. W. Bryce

K9-34

R. M. Ecker

SEQUI

M. J. Graham

K9-38

S. A. Rawson

$\mathrm{K} 9-34$

R. L. Skaggs

K9-34

P.C. Hays (last) 